\title{
USING STABLE ISOTOPES OF CARBON TO INVESTIGATE THE SEASONAL VARIATION OF CARBON TRANSFER IN A NORTHWESTERN ARKANSAS CAVE
}

\author{
Katherine J. Knierim ${ }^{1}$, Erik D. Pollock ${ }^{2}$, Phillip D. Hays ${ }^{1,3}$, and Jam Khojasteh ${ }^{4}$
}

\begin{abstract}
Stable-isotope analyses are valuable in karst settings, where characterizing biogeochemical cycling of carbon along groundwater flow paths is critical for understanding and protecting sensitive cave and karst water resources. This study quantified the seasonal changes in concentration and isotopic composition $\left(\delta^{13} \mathrm{C}\right)$ of aqueous and gaseous carbon species-dissolved inorganic carbon (DIC) and gaseous carbon dioxide $\left(\mathrm{CO}_{2}\right)$ - to characterize sources and transfer of these species along a karst flow path, with emphasis on a cave environment. Gas and water samples were collected from the soil and a cave in northwestern Arkansas approximately once a month for one year to characterize carbon cycling along a conceptual groundwater flow path. In the soil, as the DIC concentration increased, the isotopic composition of the DIC became relatively lighter, indicating an organic carbon source for a component of the DIC and corroborating soil DIC as a proxy for soil respiration. In the cave, a positive correlation between DIC and surface temperature was due to increased soil respiration as the organic carbon signal from the soil was transferred to the cave environment via the aqueous phase. $\mathrm{CO}_{2}$ concentration was lowest in the cave during colder months and increased exponentially with increasing surface temperature, presumably due to higher rates of soil respiration during warmer periods and changing ventilation patterns between the surface and cave atmosphere. Isotopic disequilibrium between $\mathrm{CO}_{2}$ and DIC in the cave was greatest when $\mathrm{CO}_{2}$ concentration was changing during November/ December and March/April, presumably due to the rapid addition or removal of gaseous $\mathrm{CO}_{2}$. The isotopic disequilibrium between DIC and $\mathrm{CO}_{2}$ provided evidence that cave $\mathrm{CO}_{2}$ was a mixture of carbon from several sources, which was mostly constrained by mixture between atmospheric $\mathrm{CO}_{2}$ and soil $\mathrm{CO}_{2}$. The concentration and isotopic composition of gaseous and aqueous carbon species were controlled by month-to-month variations in temperature and precipitation and provided insight into the sources of carbon in the cave. Stable carbon isotope ratios provided an effective tool to explore carbon transfer from the soil zone and into the cave, identify carbon sources in the cave, and investigate how seasonality affected the transfer of carbon in a shallow karst system.
\end{abstract}

\section{INTRODUCTION}

The carbon cycle is one of the most energetic biogeochemical cycles on the planet. Understanding processes such as photosynthesis, respiration, dissolution, and precipitation that exchange carbon between reservoirs, including surface water, groundwater, bedrock, soil, biomass, and the atmosphere, is important for quantifying carbon cycling and has applications for carbon sequestration (Trautz et al., 2013), paleoclimate reconstruction (Spötl et al., 2005; Wong et al., 2011), and nutrient management (Lohse et al., 2009). Stable-isotope analysis is a useful tool for understanding the exchange of carbon between reservoirs, because biogeochemical reactions change isotopic compositions in predictable ways (Kendall, 1998). Carbon isotopes $\left(\delta^{13} \mathrm{C}\right)$ are particularly useful in karst settings, where characterizing biogeochemical cycling along groundwater flow paths is critical for understanding and protecting sensitive cave and karst water resources
(Doctor et al., 2006; Graening and Brown, 2000; Katz et al., 1997; Lee and Krothe, 2001).

The amount of inorganically derived carbon in karst depends on groundwater $\mathrm{pH}$, temperature, and the relative openness of the system for continuing input of carbon dioxide $\left(\mathrm{CO}_{2}\right)$ (Fairchild et al., 2006; Palmer, 2007). In an open system, as $\mathrm{CO}_{2}$ in the soil zone reacts with and dissolves carbonate bedrock $\left(\mathrm{CaCO}_{3}\right)$, soil $\mathrm{CO}_{2}$ is continuously replenished, but in a closed system, the $\mathrm{CO}_{2}$ is ultimately consumed by reaction with $\mathrm{CaCO}_{3}$ (Clark and Fritz, 1997; Palmer, 2007). Epigenetic dissolution by these

\footnotetext{
${ }^{1}$ Department of Geosciences, 216 Ozark Hall, University of Arkansas, Fayetteville, AR 72701, USA

${ }^{2}$ University of Arkansas Stable Isotope Lab, 850 W. Dickson Street, University of Arkansas, Fayetteville, AR 72701, USA

${ }^{3}$ U.S. Geological Survey, Arkansas Water Science Center, 700 W. Research Center Blvd., Fayetteville, AR 72701, USA

${ }^{4}$ Educational Statistics and Research Methods Program, 324 Graduate Education Building, University of Arkansas, Fayetteville, AR 72701, USA
} 
processes occurs in the absence of deep sources of acidity that are found in hypogene systems (Palmer, 2007). The concentration and isotopic composition of dissolved inorganic carbon (DIC) is controlled by combined soil $\mathrm{CO}_{2}$ and bedrock $\mathrm{CaCO}_{3}$ inputs. DIC concentration for closed systems will be lower and $\delta^{13} \mathrm{C}$-DIC will be enriched in ${ }^{13} \mathrm{C}$ (i.e., heavier) because of a greater proportion of bedrock-derived carbon compared to open systems (Clark and Fritz, 1997; Fairchild et al., 2006). Carbon-isotope fractionation results from exchange of gaseous $\mathrm{CO}_{2}$ and aqueous DIC, which is dominated by bicarbonate $\left(\mathrm{HCO}_{3}^{-}\right)$ between $\mathrm{pH}$ of 6.4 and 10.3, and isotopic enrichment $\left(\varepsilon^{13} \mathrm{C}_{\mathrm{HCO}_{3}-\mathrm{CO}_{2}(\mathrm{~g})}\right)$ is approximately $7.9 \%$ at $25{ }^{\circ} \mathrm{C}$ (Clark and Fritz, 1997).

Inorganic carbon from the atmosphere and soil zones can be transferred into the cave environment via gaseous or aqueous phases; atmospheric $\mathrm{CO}_{2}$ can be drawn into caves by temperature and pressure contrasts (Kowalczk and Froelich, 2010; Palmer, 2007), soil $\mathrm{CO}_{2}$ can sink into caves via fractures in bedrock (Palmer, 2007), and $\mathrm{CO}_{2}$ can degas from infiltrating drip water when the water is supersaturated with aqueous $\mathrm{CO}_{2}$ compared to gaseous $\mathrm{CO}_{2}$ in the cave atmosphere (Spötl et al., 2005). How these carbon sources are transferred in to and out of the cave controls the geochemistry of the cave atmosphere and water (Tooth and Fairchild, 2003). For example, prior calcite precipitation is a mechanism distinct from rockwater interaction that can control calcium $(\mathrm{Ca})$ and magnesium $(\mathrm{Mg})$ concentrations due to $\mathrm{CO}_{2}$ degassing in voids, causing calcite precipitation along the groundwater flow path prior to entry into the cave (Spötl et al., 2005; Tooth and Fairchild, 2003; Wong et al., 2011). In karst, characterizing inorganic carbon sources and transformations helps define heterogeneous groundwater flow paths for meteoric water as it flows through the soil zone, epikarst, and into groundwater aquifers (Lee and Krothe, 2001).

Karst hydrogeology dominates northwestern Arkansas, and intense agricultural activities and rapid population growth in the region have led to degraded water quality (Davis et al., 2000; Graening and Brown, 2000). Nationally, Arkansas is ranked second in broiler-chicken production and fourth in turkey production, and three of the top five counties in Arkansas for agricultural sales are in the northwestern region of the state (U.S. Department of Agriculture, 2002; U.S. Department of Agriculture, 2007). Organic matter, nutrients, and bacteria from animal waste can contribute to non-point-source pollution of surface water and groundwater (Boyer and Pasquarell, 1999; Pronk et al., 2006), especially in karst, where direct connections between the surface and subsurface cause rapid transfer of contaminants into springs, caves, and groundwater aquifers (Davis et al., 2000; Graening and Brown, 2000; Johnson, 2008). To better protect these sensitive karst systems, the carbon transfer, which is ubiquitous in karst, needs to be better quantified because

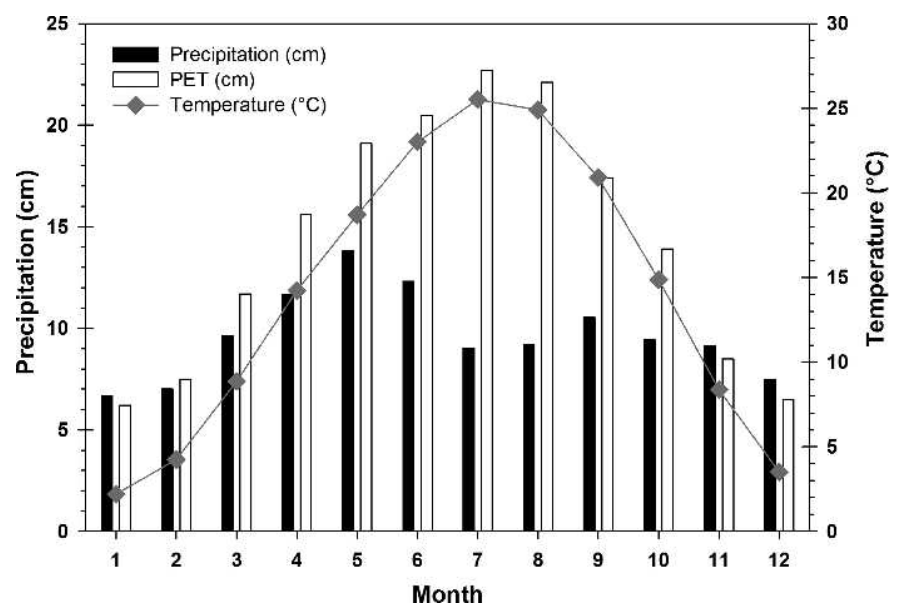

Figure 1. Monthly temperature and precipitation averages based on records from 1895 to 2009 for the Northwest Arkansas Division (National Oceanic and Atmospheric Administration, 2009). Potential evapotranspiration (PET) was calculated by Brye et al. (2004) using a modified form of the Penman-Montieth equation.

of the close linkages between inorganic and organic carbon reservoirs (Lohse et al., 2009; Winston, 2006).

Compared to the body of work from, for example, Ireland (Baldini et al., 2006; Baldini et al., 2008; Tooth and Fairchild, 2003) and Texas (Breecker et al., 2012; Wong and Banner, 2010; Wong et al., 2011), little work has been completed in northwestern Arkansas on inorganic carbon transfer. This study provides quantification of approximately monthly changes in concentration and isotopic composition of aqueous DIC and gaseous $\mathrm{CO}_{2}$ carbon species in a shallow karst hydrologic system and characterization of source inputs and transformations of these carbon species along a conceptual groundwater flow path, with emphasis on behaviors in a cave environment in northwestern Arkansas. Year-long data sets are particularly useful in areas like Arkansas where water quality changes throughout the year due to seasonal variation in temperature and precipitation (Davis et al., 2000; Winston, 2006).

\section{Study Site}

The study site is located in the southern portion of the Ozark Plateau physiographic province, which receives an average $112 \mathrm{~cm}$ of precipitation annually (Adamski et al., 1995). Annual precipitation shows a bimodal distribution (Fig. 1); precipitation peaks in May with a monthly average of $13.8 \mathrm{~cm}$, and a second, lower maximum typically occurs in September with a monthly average of $10.5 \mathrm{~cm}$ (National Oceanic and Atmospheric Administration, 2009). Average summer air temperature (June, July, August) is $24.5{ }^{\circ} \mathrm{C}$ and winter (December, January, February) is $3.3{ }^{\circ} \mathrm{C}$ (National Oceanic and Atmospheric 


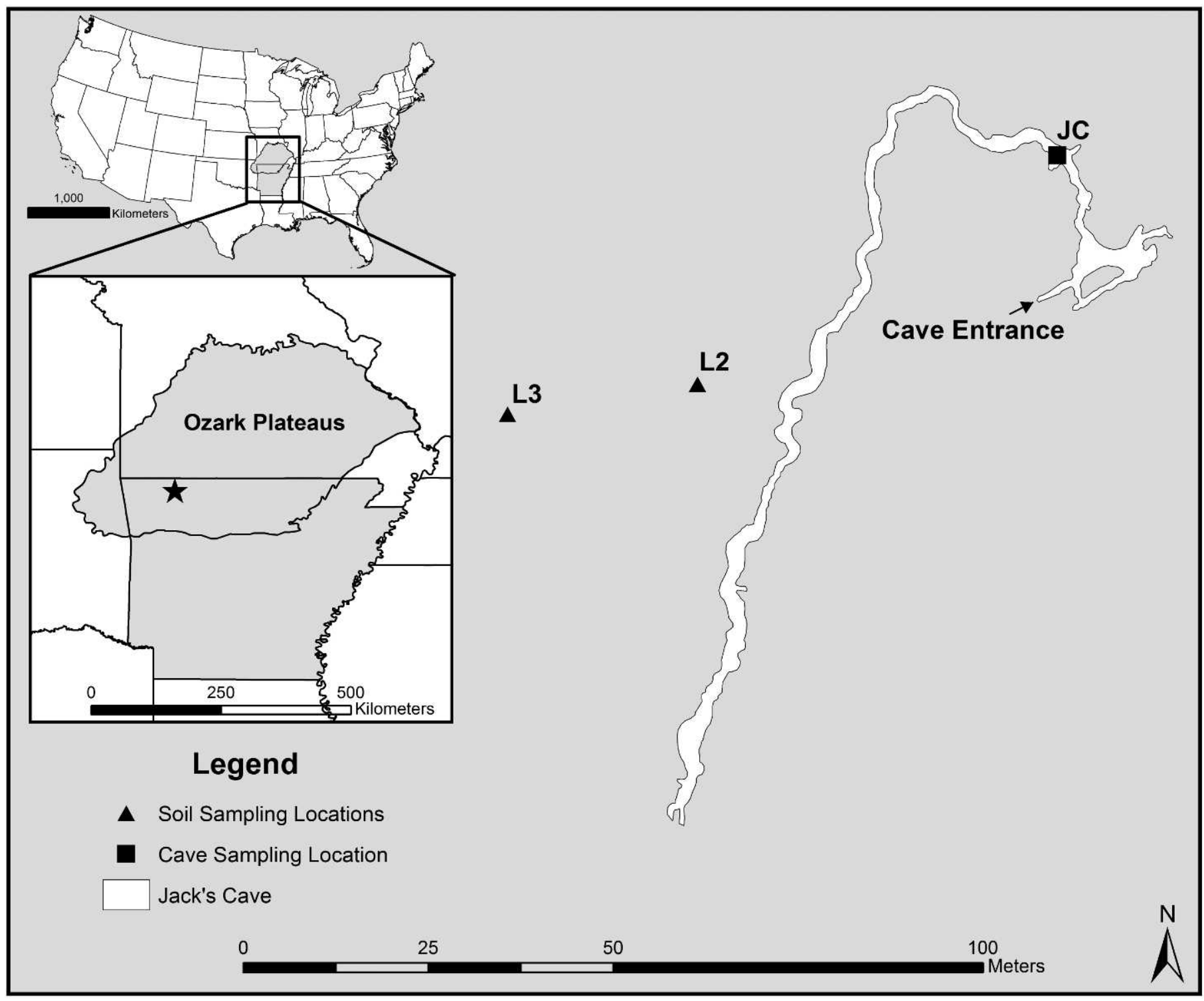

Figure 2. The study area is located in the southern part of the Ozark Plateaus in northwestern Arkansas (star). Lysimeters were installed in the soil above the cave (L2 and L3). Infiltrating water collects in a drip-water pool (JC) in the main room of Jacks's Cave and flows along the cave passage towards the southwest.

Administration, 2009). Potential evapotranspiration (PET) follows seasonal temperature patterns, being highest during the summer and lowest during the winter (Brye and West, 2004; Fig. 1).

The Ozarks in the study area consist of Paleozoic carbonate and clastic lithologies incised by streams to create valleys (Adamski et al., 1995). The lithostratigraphy at the study site, located in northwestern Arkansas (Fig. 2), includes Mississippian and Ordovician age bedrock; Devonian and Upper Ordovician units are missing due to local thinning on the flanks of an anticline to the south (Johnson, 2008). Higher hills are capped by Mississippian limestone of the Boone Formation, which includes the St. Joe Member. The entrance to Jack's Cave is a fracture in the Ordovician Kings River Sandstone Member (less than $10 \mathrm{~m}$ thick) of the Everton Formation and the cave is developed in an underlying Everton Formation dolomite unit. Jack's Cave is representative of the physical and chemical hydrogeology of caves and karst in northwestern Arkansas. The morphology of most caves in the Ozarks is that of single passages controlled by joints that terminate in narrowing, sediment-filled rooms (Taylor et al., 2009).

The study site is a mix of forest and pasture. Cattle were grazed on the property until the 1990s, when efforts to restore the native ecosystem were initiated and agricultural activities ceased. Open areas are mowed yearly to stimulate growth of native grasses and disrupt encroachment by herbaceous and woody plants. Soils are very gravely, silty 
loam, and thickness varies depending on slope, but is generally less than 1 to $2 \mathrm{~m}$ (Natural Cooperative Soil Survey, 2008).

Meteoric water recharges the shallow groundwater system at the site via diffuse flow through the soil and bedrock matrix and rapid flow via fractures in the limestone and sandstone (Knierim et al., 2011). Numerous springs discharge from the base of the St. Joe Member where the Kings River Sandstone Member perches infiltrating water. Soil water above Jack's Cave infiltrates through the Kings River Sandstone Member caprock along fractures, collects in a small drip-water pool approximately $1 \mathrm{~m}$ wide by $0.1-\mathrm{m}$ deep, and flows along the cave passage from the in-cave sampling site JC initially towards the northwest, then towards the southwest (Fig. 2). This inflow to the cave typically ceases during the period of high evapotranspiration in the summer months (Fig. 1). Direct hydrologic connections between the soil and cave were observed at the study site during a separate experiment using isotopic tracers; travel times for water released at the surface and observed in the drip-water pool ranged from approximately $0.5 \mathrm{hr}$ to $22 \mathrm{hr}$ during a dry period in early September, depending on the rate of discharge (Knierim et al., 2011).

The discharge points of the cave waters have not been identified (Knierim, 2009). Springs discharging below the cave level from the dolomite units of the Everton Formation are typically smaller than those discharging above the St. Joe/Kings River contact. The lower and upper springs combine into surface drainages that flow south approximately $0.8 \mathrm{~km}$ to Rockhouse Creek or east approximately $1 \mathrm{~km}$ to the Kings River. The Kings River regionally controls base level at approximately $335 \mathrm{~m}$ above sea level.

\section{Materials And Methods}

\section{Sample Collection and Laboratory Analysis}

Gas and water samples were collected from downslope (L2) and upslope (L3) soil lysimeters installed less than 1-m deep and in the cave (JC) approximately once a month from August 2008 until July 2009 to characterize carbon cycling along a conceptual groundwater flow path (Fig. 2). Meteoric water flows through the soil, along fractures in the Kings River Sandstone Member, and into Jack's Cave (Knierim et al., 2011). Therefore, samples collected from L2 and L3 are representative of soil gas and water above the cave. Samples were not collected from all locations on the same date because of time constraints.

For the analysis of the isotopic composition of gaseous $\mathrm{CO}_{2}\left(\delta^{13} \mathrm{C}-\mathrm{CO}_{2}\right)$, gas samples were collected from L2, L3, and $\mathrm{JC}$ into pre-combusted $100 \mathrm{~mL}$ serum vials purged with helium. Soil-gas samples were pumped from the lysimeters, and cave gas samples were collected adjacent to the drip-water pool at site JC (Fig. 2). During sample collection, a Vaisala CARBOCAP handheld carbon dioxide meter was used to measure the concentration of $\mathrm{CO}_{2}$. Gas samples were analyzed for $\delta^{13} \mathrm{C}-\mathrm{CO}_{2}$ at the University of Arkansas Stable Isotope Laboratory in Fayetteville, Arkansas, on a gas-chromatography combustion isotope-ratio mass spectrometer (IRMS).

Water samples were pumped from lysimeters at sites L2 and L3 and collected from the drip-water pool at site JC. Physical parameters, including water temperature, conductivity, and $\mathrm{pH}$, were measured in the cave pool during sample collection. Water samples for isotopic analyses of DIC $\left(\delta^{13} \mathrm{C}\right.$-DIC) were filtered through $0.7-\mu \mathrm{m}$ filters into pre-combusted total organic carbon vials and chilled to 4 ${ }^{\circ} \mathrm{C}$ until samples were analyzed at the Colorado Plateau Stable Isotope Laboratory in Flagstaff, Arizona, on a total organic carbon analyzer interfaced to an IRMS following a procedure modified from St-Jean (2003). Water samples for cations and anions were collected in high-density polyethylene bottles provided by the Arkansas Department of Environmental Quality and analyzed at their laboratory in Little Rock, Arkansas. Cations were analyzed on an inductively coupled plasma mass spectrometer; only the $\mathrm{Ca}$ and $\mathrm{Mg}$ data will be discussed.

Bedrock samples from the Mississippian Boone Formation and the Ordovician Everton Formation were collected from above and within the cave, respectively, for carbon isotopic analysis $\left(\delta^{13} \mathrm{C}-\mathrm{CaCO}_{3}\right)$. Samples were analyzed at the University of Arkansas on a Delta Plus XP isotope-ratio mass spectrometer interfaced with a Gas Bench II universal headspace sampler (Révész et al., 2002). All carbon-isotope ratios are reported relative to the Vienna Peedee Belemnite (Coplen, 1996). See Knierim (2009) for further details on sampling and analysis procedures.

\section{Data Analysis}

One-way Analysis of Variance (ANOVA) and Tukey's post-hoc tests were completed to assess differences in concentration and isotopic composition of carbon species among sites (SAS 9.3). Correlation coefficients were calculated between the concentration and isotopic composition of each carbon species $\left(\mathrm{CO}_{2}\right.$ versus $\delta^{13} \mathrm{C}-\mathrm{CO}_{2}$ and DIC versus $\delta^{13} \mathrm{C}$-DIC) for the soil and cave sites (SAS 9.3). All correlation analyses were completed using an alpha of 0.05 , and $p$-values are provided where correlations were significant. Average values are reported with plus or minus one standard deviation.

The concentrations and stable isotope ratios of $\mathrm{CO}_{2}$ and DIC were compared with meteorological data to characterize approximately monthly changes in carbon cycling. Daily minimum surface temperature and daily precipitation data from a NOAA weather station at Huntsville, Arkansas, located approximately $23 \mathrm{~km}$ southwest of the study site, were averaged for the 14-day period prior to and including the date of sample collection (Fig. 3). The 14-day averages eliminated short-term fluctuations in temperature and precipitation. Linear and exponential regressions were

Journal of Cave and Karst Studies, April 2015•15 


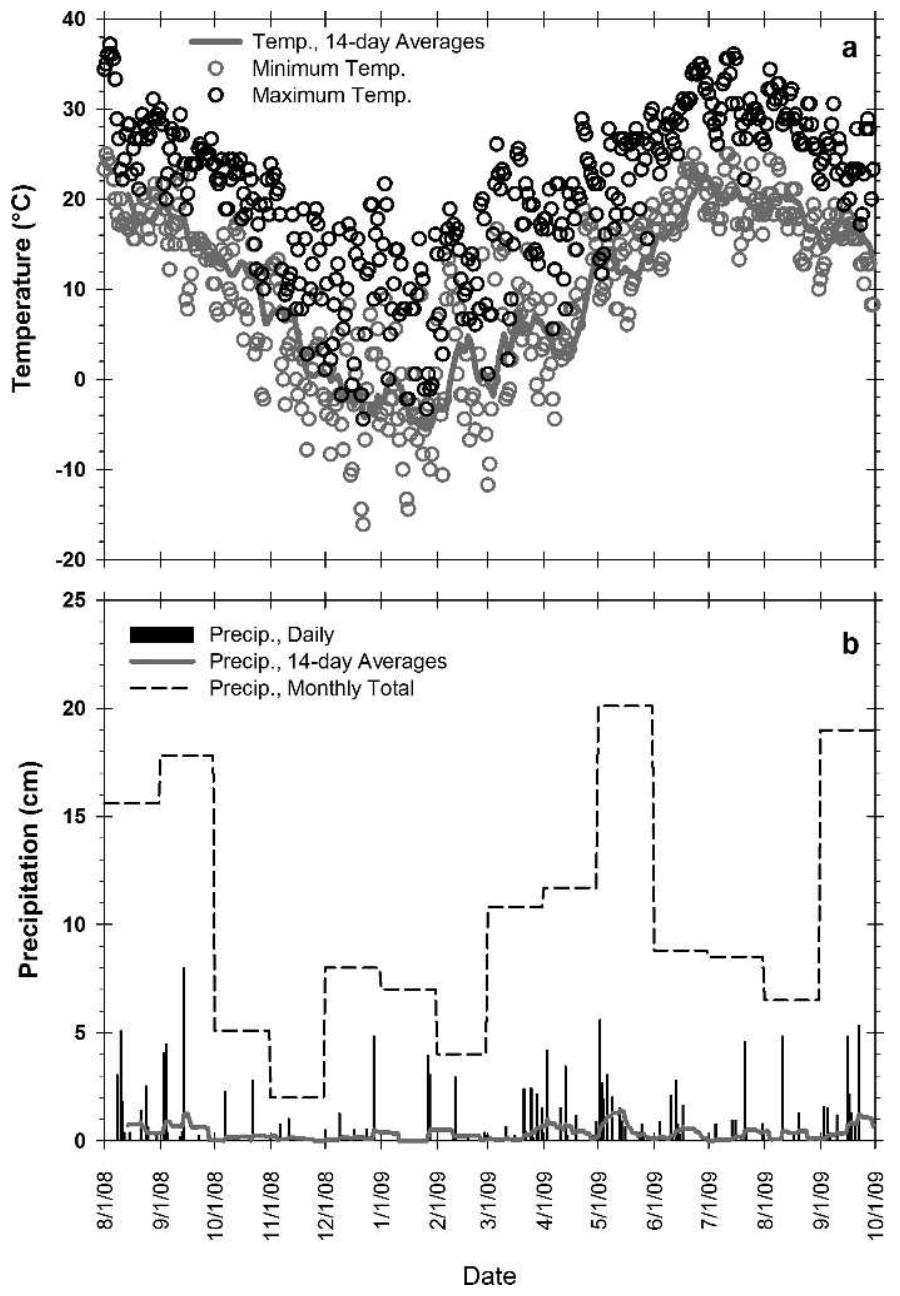

Figure 3. During the period of the study from 2008 to 2009, temperature and precipitation followed patterns similar to historical averages (Fig. 1). 14-day moving averages of daily precipitation and minimum daily temperature are shown because these are the data, taken for the sample dates, which are used in calculations, Figures 5 and 8 , and the tables.

completed on the geochemical and isotopic data and compared to the 14-day temperature and precipitation averages to determine any relationships. Regressions were focused on monthly blocks of time because northwestern Arkansas experiences seasonal changes in temperature and precipitation (Fig. 1). Important regressions between carbon and temperature /precipitation data are discussed, but were not explicitly tested for statistical significance.

Equilibrium calculations of carbon species were completed for the cave water and atmosphere. Calcite saturation was calculated using the $\log$ ratio of the ion activity product to the solubility product (Palmer 2007), where the activities for $\mathrm{Ca}$ and $\mathrm{CO}_{3}^{2-}$ were calculated using the Debye-Hückel equation for solutions with ionic strengths less than 0.1 (Fetter, 2001). The differences in isotopic composition between DIC in the cave pool and $\mathrm{CO}_{2}$ in the cave atmosphere $\left(\Delta^{13} \mathrm{C}_{\mathrm{DIC}_{-} \mathrm{CO}_{2}(\mathrm{~g})}\right)$ were com- pared to temperature and $\mathrm{pH}$ dependent equilibrium fractionation values, where $\Delta^{13} \mathrm{C}_{\mathrm{DIC}-\mathrm{CO}_{2}(\mathrm{~g})}$ is an approx-

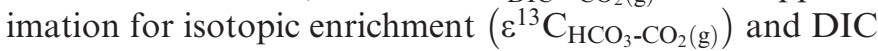
is assumed to be dominated by $\mathrm{HCO}_{3}^{-}$(Clark and Fritz, 1997). Using the proportion of individual carbon species as controlled by $\mathrm{pH}$ and temperature, the gross isotopic enrichment between DIC and $\mathrm{CO}_{2}\left(\varepsilon^{13} \mathrm{C}_{\mathrm{DIC}_{-}-\mathrm{CO}_{2}(\mathrm{~g})}\right)$ was also calculated (Clark and Fritz, 1997; Peyraube et al., 2013) for comparison to the empirically derived $\varepsilon^{13} \mathrm{C}_{\mathrm{HCO}_{3}-\mathrm{CO}_{2}(\mathrm{~g})}$ values.

Possible sources of cave $\mathrm{CO}_{2}$ were assessed using a concentration-dependent, two-component mixing model (Faure, 1986) that constrains the isotopic composition of end-member $\mathrm{CO}_{2}$ sources (i.e., $\delta^{13} \mathrm{C}-\mathrm{CO}_{2}$ ) using the following equations:

$$
\delta_{\text {cave }}=\frac{a}{X_{\text {cave }}}+b
$$

where

$$
\begin{aligned}
& X_{\text {cave }}=f X_{\mathrm{atm}}+(1-f) X_{\text {end }}, \\
& a=\frac{X_{\mathrm{atm}} X_{\text {end }}\left(\delta_{\text {end }}-\delta_{\mathrm{atm}}\right)}{X_{\mathrm{atm}}-X_{\text {end }}},
\end{aligned}
$$

and

$$
b=\frac{X_{\mathrm{atm}} \delta_{\mathrm{atm}}-X_{\text {end }} \delta_{\text {end }}}{X_{\mathrm{atm}}-X_{\text {end }}} .
$$

where $X$ is the concentration of $\mathrm{CO}_{2}, \delta$ is $\delta^{13} \mathrm{C}-\mathrm{CO}_{2}$, and $f$ is the proportion of an end-member from 0 to 1 , or no contribution to $100 \%$ contribution. See Faure (1986) for a full derivation of the equations.

One source of $\mathrm{CO}_{2}$ to the cave was assumed to be atmospheric $\mathrm{CO}_{2}$, with a $\mathrm{CO}_{2}$ concentration $\left(X_{\mathrm{atm}}\right)$ of $380 \mathrm{ppm}$ (Palmer, 2007) and an isotopic composition $\left(\delta_{\mathrm{atm}}\right)$ of $-7.7 \%$ (Faure and Mensing, 2005), so that the isotopic composition of the second end-member source $\left(\delta_{\text {end }}\right)$ was calculated at $f$ equal to 0 . Equation 1 was calculated iteratively to graphically find the two mixing lines that would bracket the observed $\mathrm{CO}_{2}$ data. Concentrationdependent mixing models are important to use when the concentration of an element such as carbon varies between the two end-member sources, which can induce error in calculations of isotopic composition if a linear mixing model is used (Phillips and Koch, 2002).

\section{Results}

\section{CARbon Dioxide}

Gaseous $\mathrm{CO}_{2}$ concentrations ranged between 1,400 and $19,450 \mathrm{ppm}$ in the soil, and L2 exhibited lower $\mathrm{CO}_{2}$ than L3 (Table 1). Soil $\mathrm{CO}_{2}$ was lowest from January through March, excluding one high value of 8,000 ppm for L2 in March (Fig. 4a). $\mathrm{CO}_{2}$ increased at L3 between March and April. At L2, $\mathrm{CO}_{2}$ decreased after a March increase and 


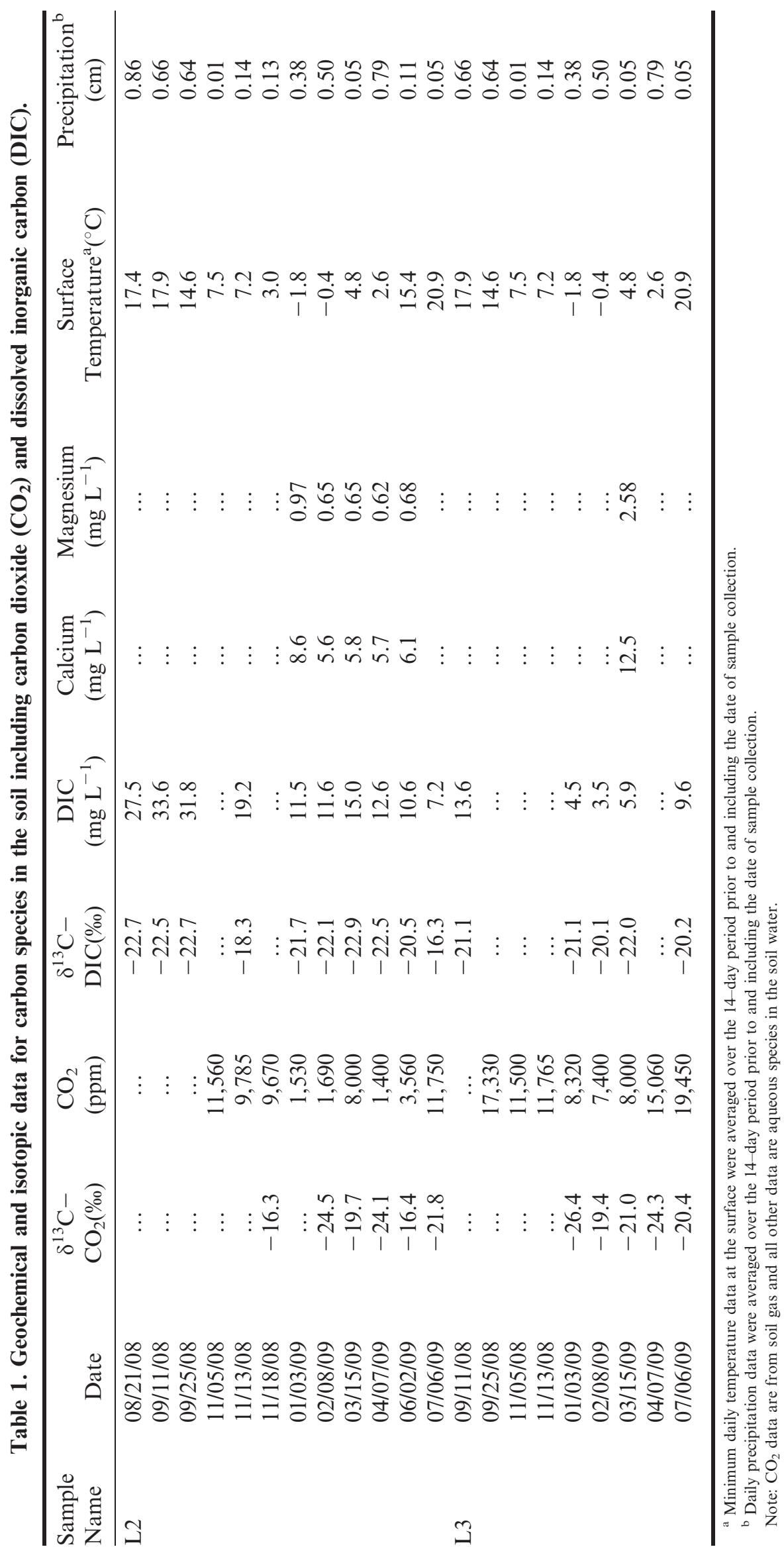



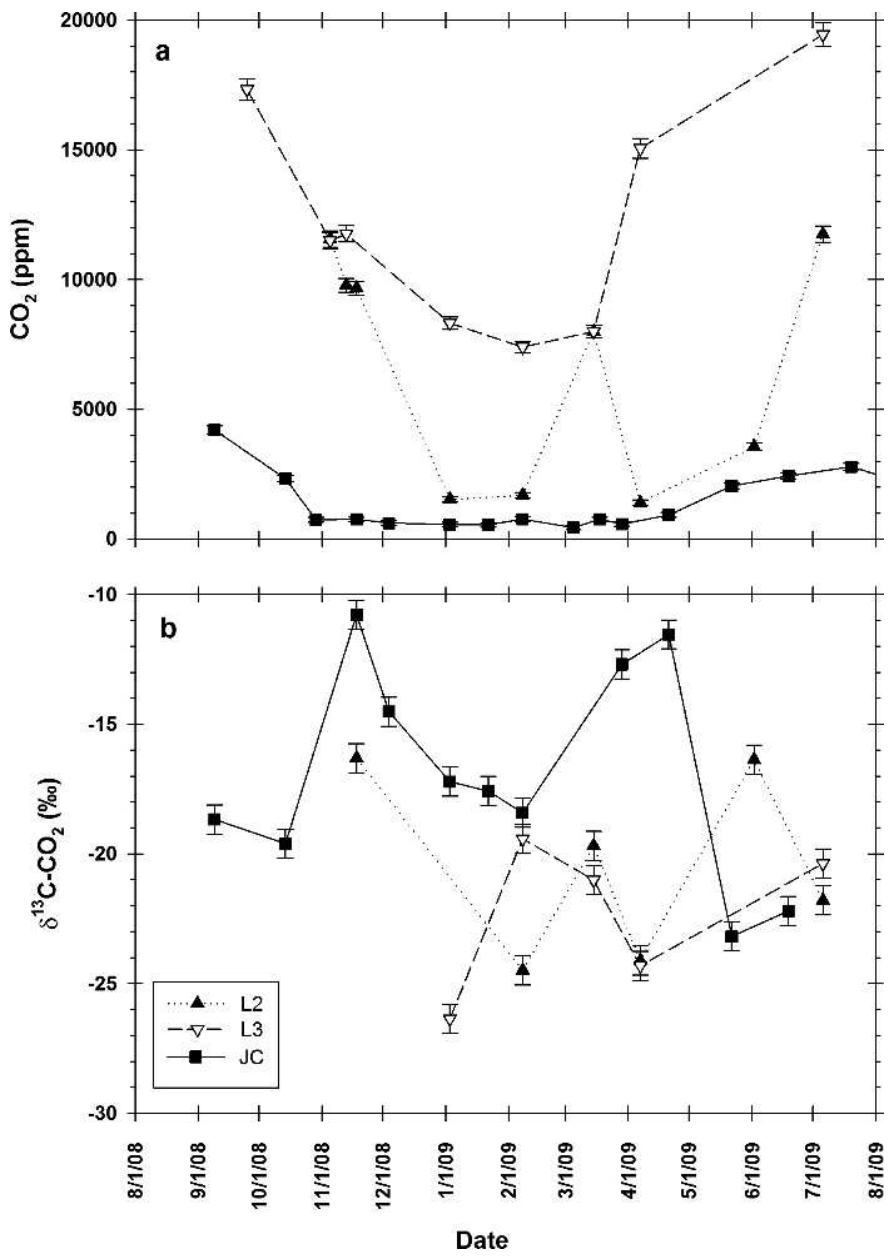

Figure 4. Gaseous soil (L2 and $\mathrm{L3}$ ) and cave (JC) $\mathrm{CO}_{2}$ concentration and $\delta^{13} \mathrm{C}-\mathrm{CO}_{2}$ from August 2008 to August 2009. Error bars show analytical precision.

began to increase again by June. $\mathrm{CO}_{2}$ showed a positive, exponential relationship with surface temperature at L3 $\left(r^{2}=0.68\right)$ and a weaker relationship at $\mathrm{L} 2\left(r^{2}=0.30\right.$, Fig. 5a). Soil $\mathrm{CO}_{2}$ concentration decreased exponentially in L2 with increasing precipitation $\left(r^{2}=0.75\right)$, but no such relationship was observed in L3 (Fig. 5b).

Soil $\delta^{13} \mathrm{C}-\mathrm{CO}_{2}$ ranged between $-16.3 \%$ and $-26.4 \%$ at both soil sites (Fig. $4 \mathrm{~b}$ ). $\delta^{13} \mathrm{C}-\mathrm{CO}_{2}$ became lighter with increasing precipitation in L2 only $\left(r^{2}=0.51\right.$, Fig. $\left.5 \mathrm{~d}\right)$. Samples from June to November (summer through fall) at L2 and L3 generally had greater $\mathrm{CO}_{2}$ concentrations and the $\delta^{13} \mathrm{C}_{-} \mathrm{CO}_{2}$ values became more negative with increasing $\mathrm{CO}_{2}$, but the relationship was not statistically significant (Table 1). The concentration of $\mathrm{CO}_{2}$ decreased between January and April (winter through spring), but did not clearly correlate with isotopic composition.

Atmospheric $\mathrm{CO}_{2}$ concentrations at in-cave site $\mathrm{JC}$ ranged from 440 to $4,210 \mathrm{ppm}$ (Table 2). Average $\mathrm{CO}_{2}$ was $662 \mathrm{ppm}$ from November to April and 2,668 ppm from May to October. $\mathrm{CO}_{2}$ changed rapidly between seasons; $\mathrm{CO}_{2}$ decreased by $1,570 \mathrm{ppm}$ between October and
November and increased by 1,120 ppm between April and May (Fig. 4a). $\mathrm{CO}_{2}$ was lowest during the colder months and increased exponentially with increasing surface temperature $\left(r^{2}=0.83\right.$; Fig. 5a). No relationship was observed between precipitation and $\mathrm{CO}_{2}$ in the cave (Fig. 5b).

Cave $\delta^{13} \mathrm{C}-\mathrm{CO}_{2}$ ranged between $-10.8 \%$ and $-23.2 \%$ (Table 2). The heaviest $\delta^{13} \mathrm{C}-\mathrm{CO}_{2}$ compositions occurred in November and April (Fig. 4b). In the cave, $\delta^{13} \mathrm{C}-\mathrm{CO}_{2}$ generally became lighter with increasing surface temperature (Fig. 5c) and no relationship with precipitation was observed (Fig. 5d). Higher $\mathrm{CO}_{2}$ concentration generally corresponded with lighter isotopic composition (Fig. 6), but the relationship was not statistically significant.

$\mathrm{CO}_{2}$ concentration was significantly different among all sites; $\mathrm{CO}_{2}$ was highest at $\mathrm{L} 3$ and lowest at $\mathrm{JC}(\mathrm{F}(2,31)=$ $31.42, p<0.01)$. The isotopic composition of $\mathrm{CO}_{2}$ was significantly heavier at JC than L3 $(\mathrm{F}(2,19)=3.98, p<$ $0.05) . \mathrm{CO}_{2}$ concentration was generally lowest in the cave, and the $\delta^{13} \mathrm{C}-\mathrm{CO}_{2}$ was lightest in the soil (Fig. 6).

The $\delta^{13} \mathrm{C}-\mathrm{CO}_{2}$ compositions observed in the soil and cave were constrained by mixing between atmospheric $\mathrm{CO}_{2}$ (approximately $380 \mathrm{ppm}$ and $-7.7 \%$ ) and two lighter endmember sources with $\delta^{13} \mathrm{C}-\mathrm{CO}_{2}$ compositions of $-14 \%$ and $-30 \%$, based on iterative calculations using equations 1 through 4 (Fig. 6). Note that the isotopic compositions of $-14 \%$ and $-30 \%$ bracket all the $\delta^{13} \mathrm{C}-\mathrm{CO}_{2}$ values observed in the soil at L2 and L3 and all but two values observed in the cave at JC (January and February samples). For comparison, if the minimum and maximum observed soil $\delta^{13} \mathrm{C}-\mathrm{CO}_{2}$ compositions were used in the mixing model (i.e., $-16.3 \%$ and $-26.4 \%$ ), then more of the observed isotopic compositions from this study would lie outside of the mixing lines.

\section{Dissolved InORganic CARBon}

Dissolved inorganic carbon concentrations ranged between 3.5 and $33.6 \mathrm{mg} \mathrm{L}^{-1}$ in soil-water samples (Table 1). L2 consistently had higher DIC concentrations than L3, and both soil sites showed a decrease in concentration between September and January (Fig. 7a). DIC concentration was exponentially correlated with surface temperature in L3 $\left(r^{2}=0.85\right.$; Fig. 8a), similar to the observations of $\mathrm{CO}_{2}$. DIC at $\mathrm{L} 2$ did not show a correlation with surface temperature. No relationship between DIC in the soil and precipitation was observed (Fig. 8b).

Soil $\delta^{13} \mathrm{C}$-DIC ranged between $-22.9 \%$ and $-16.3 \%$ (average $-21.1 \%$ ) and was lighter than average cave water DIC ( $-17.3 \%$, Fig. $7 b)$. In L2, $\delta^{13} \mathrm{C}$-DIC became lighter with increasing precipitation $\left(r^{2}=0.40\right.$; Fig. 8d), similar to changes in $\delta^{13} \mathrm{C}-\mathrm{CO}_{2}$ at $\mathrm{L} 2$. An inverse relationship between seasonal DIC concentration and isotopic composition was observed in the soil in the combined data from L2 and L3 (Fig. 9); as DIC concentration increased, $\delta^{13} \mathrm{C}$ DIC values became more negative for samples from June 

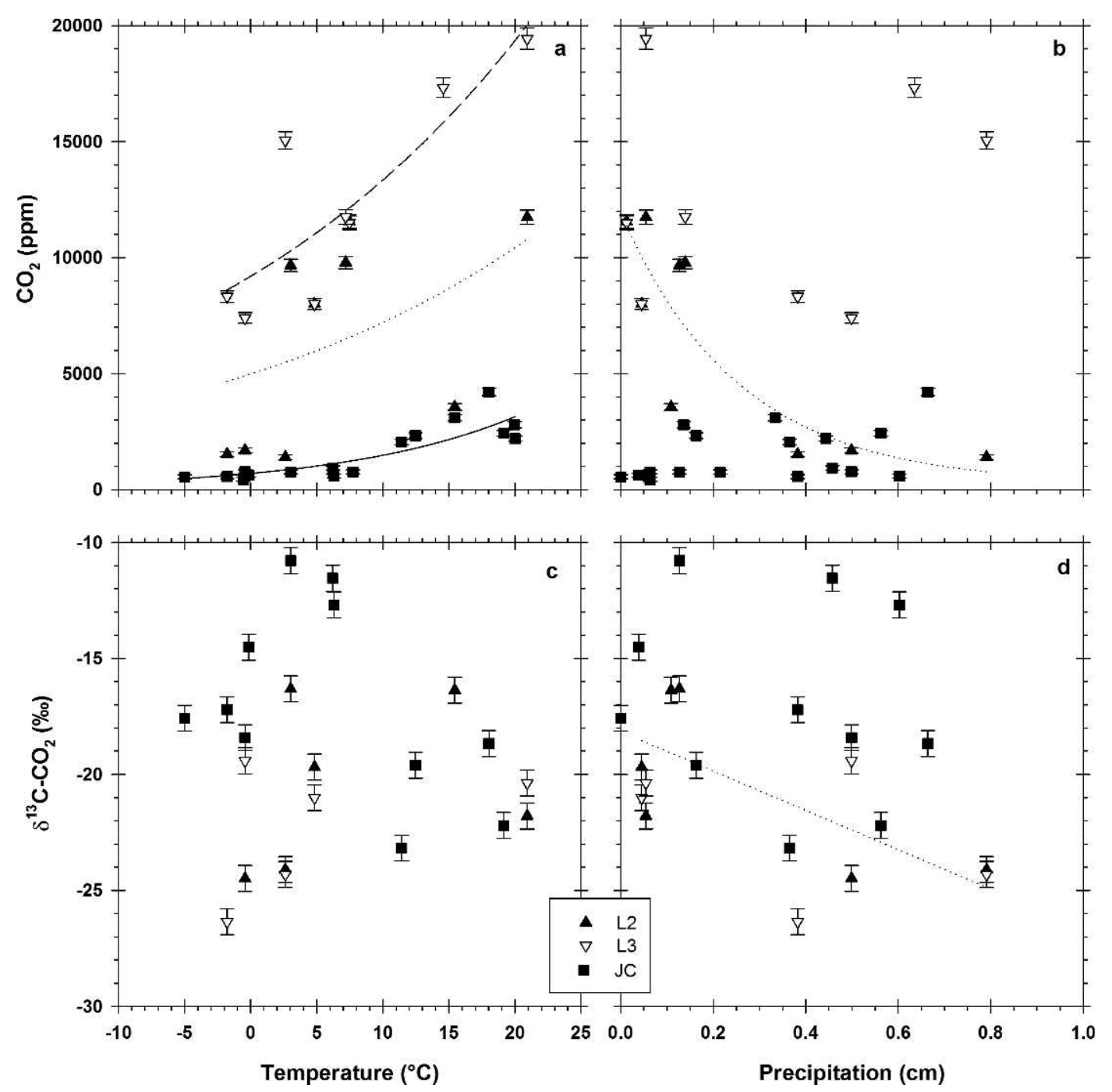

Figure 5. Gaseous soil ( $\mathrm{L} 2$ and $\mathrm{L3}$ ) and cave $(\mathrm{JC}) \mathrm{CO}_{2}$ concentration and $\delta^{13} \mathrm{C}-\mathrm{CO}_{2}$ compared to surface temperature and precipitation. Regression lines: $\mathbf{L} 2=$ short-dash line; $\mathbf{L 3}=$ long-dash line; $\mathrm{JC}=$ solid line. See text for $\mathbf{r}^{2}$ values. Error bars show analytical precision.

to November $\left(r^{2}=0.54, p<0.05\right)$ and January to April $\left(r^{2}=0.73, p<0.01\right)$ for all soil data.

DIC concentrations in the cave drip-water pool at site JC ranged between 2.0 and $21.7 \mathrm{mg} \mathrm{L}^{-1}$ (Table 2) and were generally lower than concentrations observed in the soil (Fig. 7a). Cave water DIC generally decreased from October to March, except for a high value of $21.7 \mathrm{mg} \mathrm{L}^{-1}$ in December (Fig. 7a). Cave water DIC increased exponentially with increasing surface temperature $\left(r^{2}=0.50\right)$, excluding the high DIC value of $21.7 \mathrm{mg} \mathrm{L}^{-1}$ (Fig. 8a) that was excluded using the Grubb's outlier test $(Z(13)=$ $-2.86, p<0.05)$. No relationship between DIC in the cave and precipitation was observed (Fig. 8b).

The $\delta^{13} \mathrm{C}$-DIC values in the cave ranged between $-9.5 \%$ and $-24.2 \%$ (Fig. 7b). Isotopic compositions in the fall and spring were typically lighter, with the September to November average $-19.7 \%$ and the April to June average $-20.9 \%$, than in winter, with the
December to early March average $-13.9 \%$. No relationship between $\delta^{13} \mathrm{C}$-DIC in the cave and air temperature (Fig. 8c) was observed. In the cave pool, $\delta^{13} \mathrm{C}$-DIC became lighter with increasing precipitation $\left(r^{2}=0.41\right.$, Fig. $\left.8 \mathrm{~d}\right)$.

DIC concentration was significantly higher at L2 than JC or L3 $(\mathrm{F}(2,25)=8.72, p<0.01)$, although not significantly different between L3 and JC. The isotopic composition of DIC was significantly heavier at JC than at $\mathrm{L} 2(\mathrm{~F}(2,25)=5.58, p<0.01)$. DIC concentration was generally lowest in the cave and the $\delta^{13} \mathrm{C}$-DIC was lightest in the soil (Fig. 9).

The $\Delta{ }^{13} \mathrm{C}_{\mathrm{DIC}_{-} \mathrm{CO}_{2}(\mathrm{~g})}$ values in the cave, which are an approximation of gross isotopic enrichment, were between -12.7 and $+5.1 \%$ (Fig. 10). Values for $\varepsilon^{13} \mathrm{C}_{\mathrm{HCO}_{3}-\mathrm{CO}_{2}(\mathrm{~g})}$ ranged from 8.9 to $9.3 \%$ and averaged $9.1 \%$ (Table 2), as controlled by cave water temperature (Clark and Fritz, 1997). Between $\mathrm{pH}$ of 6.4 and 10.3, DIC is dominated by $\mathrm{HCO}_{3}^{-}$(Clark and Fritz, 1997). For example, $\mathrm{HCO}_{3}{ }^{-}$ 


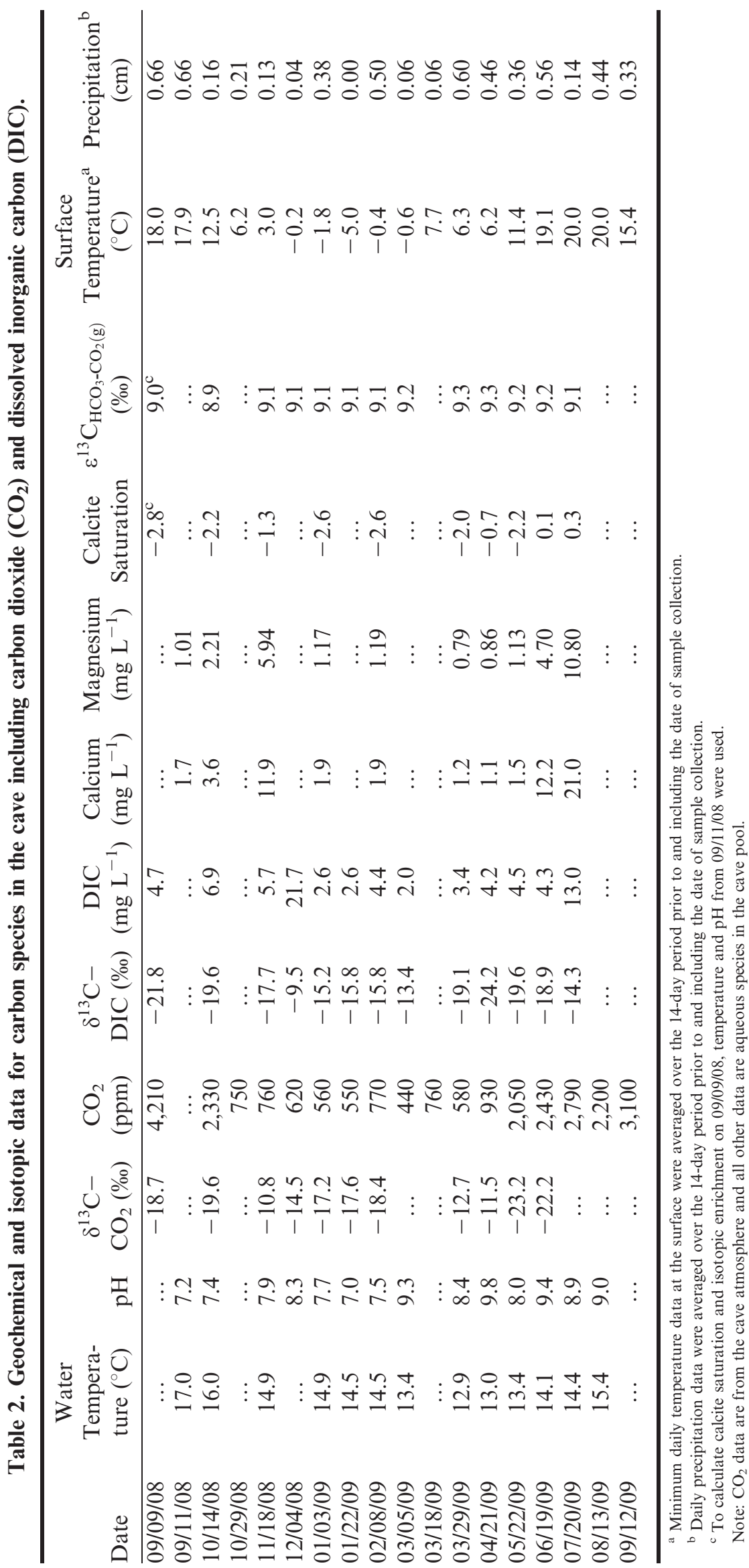




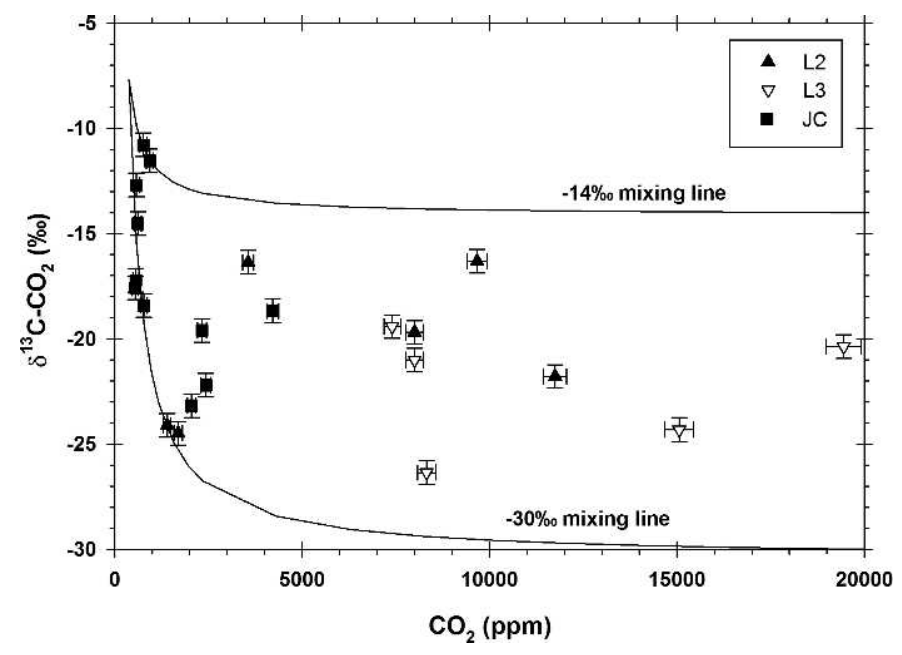

Figure 6. Gaseous soil (L2 and $\mathrm{L3})$ and cave $(\mathrm{JC}) \delta^{13} \mathrm{C}$ $\mathrm{CO}_{2}$ versus $\mathrm{CO}_{2}$ concentration. The mixing lines represent mixing of atmospheric $\mathrm{CO}_{2}(380 \mathrm{ppm}$ and $-7.7 \%)$ with two lighter end-member sources calculated to be $-14 \%$ and $-30 \%$. Error bars show analytical precision.

composed 83 to $98 \%$ of DIC at JC. The $\varepsilon^{13} \mathrm{C}_{\mathrm{DIC}_{-} \mathrm{CO}_{2}(\mathrm{~g})}$ (not shown) at JC ranged from 7.5 to $9.1 \%$ and averaged $8.4 \%$, based on $\mathrm{pH}$, temperature, and carbonate equilibria (Clark and Fritz, 1997; Peyraube et al., 2013). The observed $\Delta \Delta^{13} \mathrm{C}_{\mathrm{DIC}_{-} \mathrm{CO}_{2}(\mathrm{~g})}$ values were outside the range of equilibrium

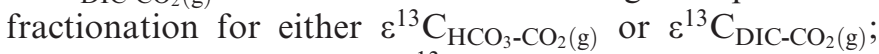

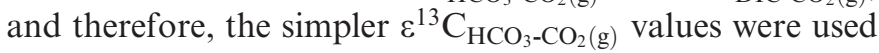
to assess the degree of isotope disequilibrium between aqueous DIC and gaseous $\mathrm{CO}_{2}$.

\section{Cations and Physical Parameters}

Soil water geochemistry data are discussed for L2 only, because L3 generally provided insufficient volume for full analyses. Generally, soil moisture was higher at L2, the downslope lysimeter, as compared to L3 upslope, based on field observations and the difficulty in collecting soil water samples from L3. In the soil water, Ca ranged between 5.6 and $8.6 \mathrm{mg} \mathrm{L}^{-1}$ and $\mathrm{Mg}$ from 0.62 to $0.97 \mathrm{mg} \mathrm{L}^{-1}$ (Table 1), and $\mathrm{Mg}$ to $\mathrm{Ca}$ ratios were mostly invariant at approximately 0.1 .

In the cave, water in the pool at JC temperature averaged $14.6{ }^{\circ} \mathrm{C} \pm 1.4$ and $\mathrm{pH}$ averaged $8.2 \pm 0.9$ (Table 2). Ca and $\mathrm{Mg}$ concentrations changed seasonally, with the lowest concentrations between January and May. Cave water was generally undersaturated with respect to calcite as the saturation indices ranged from -2.8 to 0.3 , with a median value of -2.1 . Precipitation of calcite in the cave pool was not observed during the course of this study. $\mathrm{Mg}$ to $\mathrm{Ca}$ ratios ranged from 0.4 to 0.8 in the cave water.

\section{BEDROCK}

The $\delta^{13} \mathrm{C}$ isotopic composition of bedrock samples from the St. Joe Limestone Member of the Boone Formation
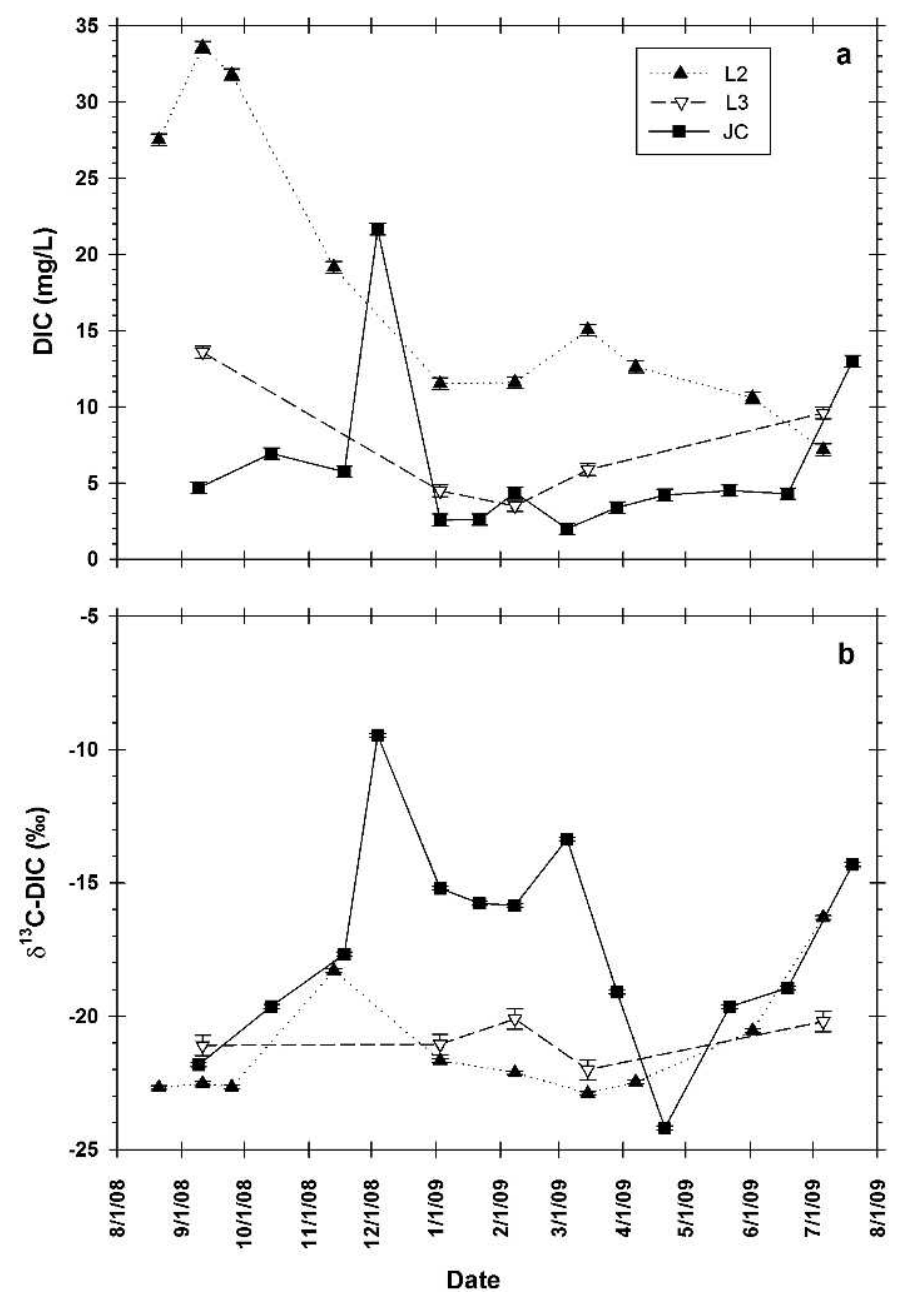

Figure 7. Aqueous soil (L2 and L3) and cave (JC) DIC concentration and $\delta^{13} \mathrm{C}$-DIC composition from August 2008 to August 2009.

and from the Everton Formation averaged $-1.4 \% 0(\mathrm{n}=2)$ and $-3.7 \%$ $\pm 0.4(\mathrm{n}=4)$, respectively. Samples collected previously from the Boone Formation in northwestern Arkansas ranged from 2.5 to $4.9 \%$ (Pollock, pers. comm.). Therefore, carbonate units in the Ozarks tend to be heavier, within the range of marine carbonates (Clark and Fritz, 1997).

\section{Discussion}

In a conceptual model of carbon inputs and transformations at the study site, aqueous DIC and gaseous $\mathrm{CO}_{2}$ are transported into Jack's Cave from the soil zone, as represented by data from $\mathrm{L} 2$ and $\mathrm{L} 3$, with cave-atmosphere $\mathrm{CO}_{2}$ also being sourced directly from the surface atmosphere (Fig. 11). The magnitude of different source inputs to the cave changed seasonally, as evidenced by the monthto-month variability of $\mathrm{CO}_{2}$ and DIC concentrations and isotopic compositions during the study period (Figs. 4 and 7). The details of the conceptual model for carbon sources 

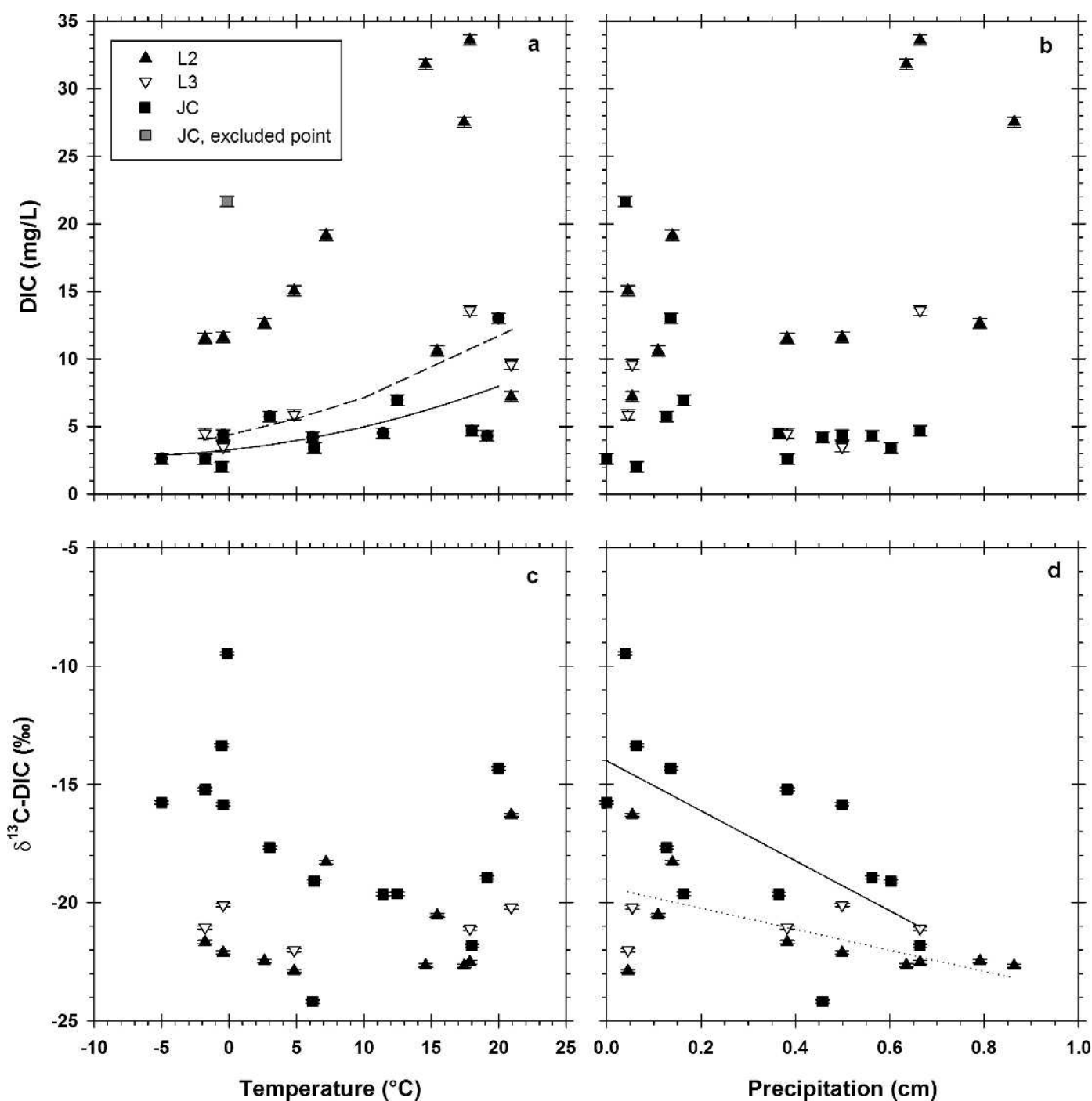

Figure 8. Aqueous soil ( $\mathrm{L} 2$ and $\mathrm{L3}$ ) and cave (JC) DIC concentration and $\delta^{13} \mathrm{C}$-DIC composition compared to surface temperature and precipitation. Regression lines: $\mathbf{L 2}=$ short-dash line; $\mathbf{L 3}=$ long-dash line; JC $=$ solid line. See text for $\mathbf{r}^{2}$ values. In 8a, one data point (gray) was excluded from the JC regression.

and transformations in this shallow karst system are discussed below.

SoIL

Qualitative differences in soil moisture between L2 and L3 contributed to how soil $\mathrm{CO}_{2}$ was affected by changes in surface temperature and precipitation at the two locations. For example, L3 was generally drier, and $\mathrm{CO}_{2}$ was more influenced by changes in surface temperature than at L2 (Fig. 5a). Surface temperature is a proxy for soil respiration; plants and microbes have greater respiration rates during the warmer months of the growing season (Davidson et al., 1998). Increased soil temperature explained $47 \%$ to $80 \%$ of the variation in soil respiration rate at a forested site in Massachusetts (Borken et al., 2003; Davidson et al., 1998), and in this study, surface temperature explained $68 \%$ of the variation in $\mathrm{CO}_{2}$ concentration at L3, the drier of the two soil sites.
Soil temperature and water content can be confounding factors influencing seasonal variation in soil respiration rates because the two factors may covary (Davidson et al., 1998). L2 was often wetter following precipitation events, and soil $\mathrm{CO}_{2}$ was influenced by the timing of precipitation (Fig. 5b and 5d). Increasing soil moisture may increase $\mathrm{CO}_{2}$ flux due to oxidation of labile organic carbon following soil wetting, although the exact mechanism of carbon release is debated (Sponseller, 2007). Soil moisture can also decrease $\mathrm{CO}_{2}$ flux at high water contents as diffusion of oxygen (and subsequent respiration) is slowed (Davidson et al., 1998). If precipitation, and a resulting increase in soil moisture, was stimulating root or microbial respiration, an increase in $\mathrm{CO}_{2}$ concentration and lighter soil $\delta{ }^{13} \mathrm{C}-\mathrm{CO}_{2}$ would be expected (Šantrůčková et al., 2000). Lighter $\delta{ }^{13} \mathrm{C}-\mathrm{CO}_{2}$ compositions were observed at L2 with increasing precipitation (Fig. 5d), but an increase in 


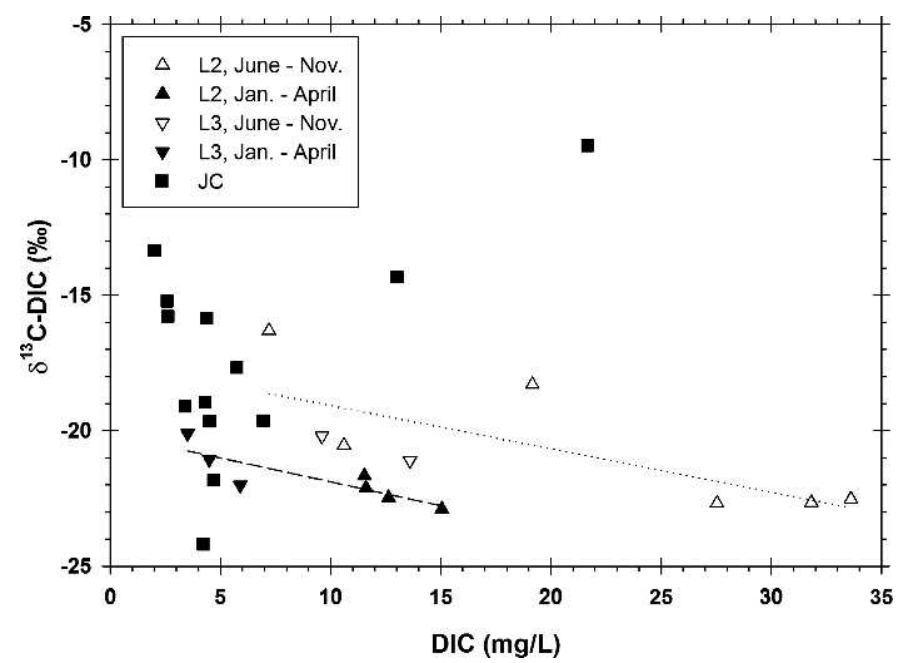

Figure 9. Aqueous soil (L2 and L3) and cave (JC) DIC isotopic composition versus concentration. Note meaning of regression lines differs from that in Figures 5 and 8. Here: June to November samples (L2 and L3) $=$ short-dash line; January to April samples (L2 and L3) = long-dash line. See text for $\mathbf{r}^{2}$ values.

$\mathrm{CO}_{2}$ concentration following precipitation was not observed (Fig. 5b). Although this study did not directly measure soil temperature and soil moisture, increasing precipitation decreased $\mathrm{CO}_{2}$ concentration in $\mathrm{L} 2$, similar to findings of Davidson et al. (1998), in which respiration rates and $\mathrm{CO}_{2}$ decreased at higher soil water contents. Alternatively, $\mathrm{CO}_{2}$ pulses from soils following precipitation have been shown to decrease to background levels within hours to days (Borken et al., 2003; Sponseller, 2007), so the sampling frequency during this study may have missed rapid increases in soil $\mathrm{CO}_{2}$.

Using precipitation as a proxy for soil moisture does not account for loss of water by evapotranspiration (ET). PET is highest during the warmer months, when rainfall is typically lower in northwestern Arkansas. The PET estimates from Brye et al. (2004) in Figure 1 are monthly totals, and calculating ET over shorter timescales from daily observations can be difficult due to the diurnal cycle of ET (Fisher et al., 2011). Additionally, actual evapotranspiration (AET) is considered in water-flux calculations, not PET, because PET represents potential energy (Fisher et al., 2011). Without measuring AET at the study site and without the additional climate data required to calculate the PET, accurately quantifying the effect of ET on water flux through the soil zone is difficult. Therefore, daily precipitation data were averaged over the preceding 14 days to represent the cycle of wetting and drying in the soil prior to sample collection.

The increase in concentration of DIC with increasing surface temperature observed in L3 (Fig. 8a) is consistent with the assumption that temperature serves as a proxy for soil respiration. Respired $\mathrm{CO}_{2}$ exchanges with soil water

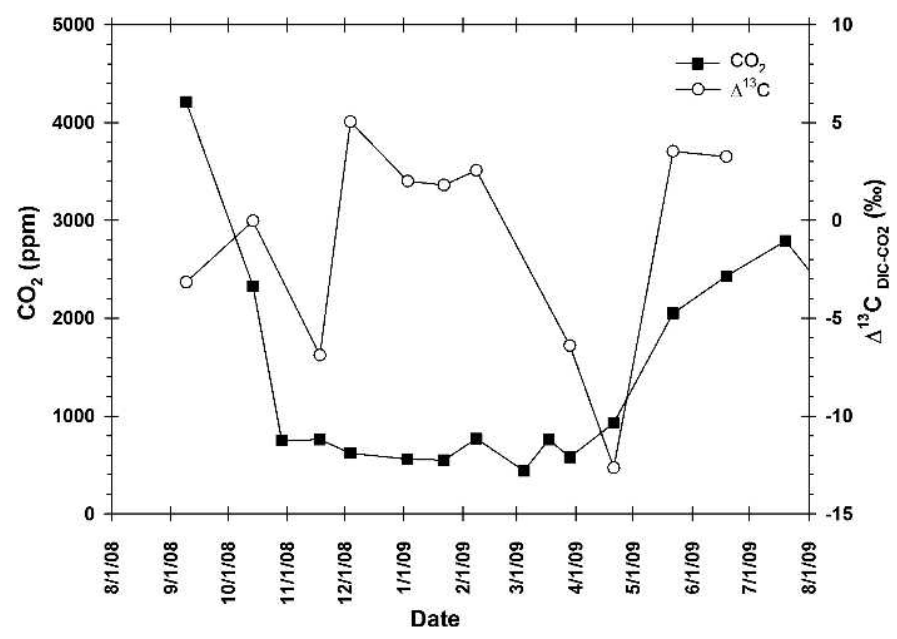

Figure 10. Temporal variability of the difference between the isotopic composition of aqueous DIC in the cave pool and gaseous $\mathrm{CO}_{2}$ in the cave atmosphere $\left(\Delta^{13} \mathrm{C}_{\mathrm{DIC}-\mathrm{CO}_{2}}\right)$ compared to $\mathrm{CO}_{2}$ concentration from August 2008 to August 2009.

and through hydration and dissociation of carbonic acid yields the various DIC species, depending on pH (Clark and Fritz, 1997). Decreasing DIC concentration during the winter has been observed elsewhere in karst environments and attributed to decreased rates of respiration (Winston, 2006). Combined data from both soil sites in this study showed a negative correlation between DIC concentration and $\delta^{13} \mathrm{C}$-DIC during both the periods June to November and January to April (Fig. 9), indicating an organic carbon source for a component of DIC and further corroborating soil DIC as a proxy for respiration. Additionally, the inverse relationship between DIC concentration and $\delta^{13} \mathrm{C}$ DIC occurred during roughly seasonal blocks of time (summer to fall and winter to spring). Similar to $\delta^{13} \mathrm{C}-\mathrm{CO}_{2}$ (Fig. 5d), $\delta^{13}$ C-DIC decreased at L2 with increasing precipitation (Fig. 8d), illustrating the exchange of carbon species between gaseous and aqueous phases in the soil zone (Fig. 11). Therefore, the isotopic composition of DIC in this shallow karst system has picked up the isotopic signature of respired soil $\mathrm{CO}_{2}$ prior to entering the cave environment (Fig. 11), and this isotopic signal is affected by changes in temperature and precipitation.

CAVE

In the cave, $\mathrm{CO}_{2}$ concentration was lowest from November to April (Fig. 4a), which is roughly winter through spring for northwestern Arkansas. A decrease in $\mathrm{CO}_{2}$ concentration during periods of cooler surface temperatures has been observed in caves from other areas (Baldini et al., 2008; Spötl et al., 2005), because changes in surface temperature create density contrasts with cave air, resulting in ventilation patterns that alternate seasonally (Palmer, 2007). Lower soil temperatures also decrease rates of soil respiration (Borken et al., 2003; Davidson et al., 


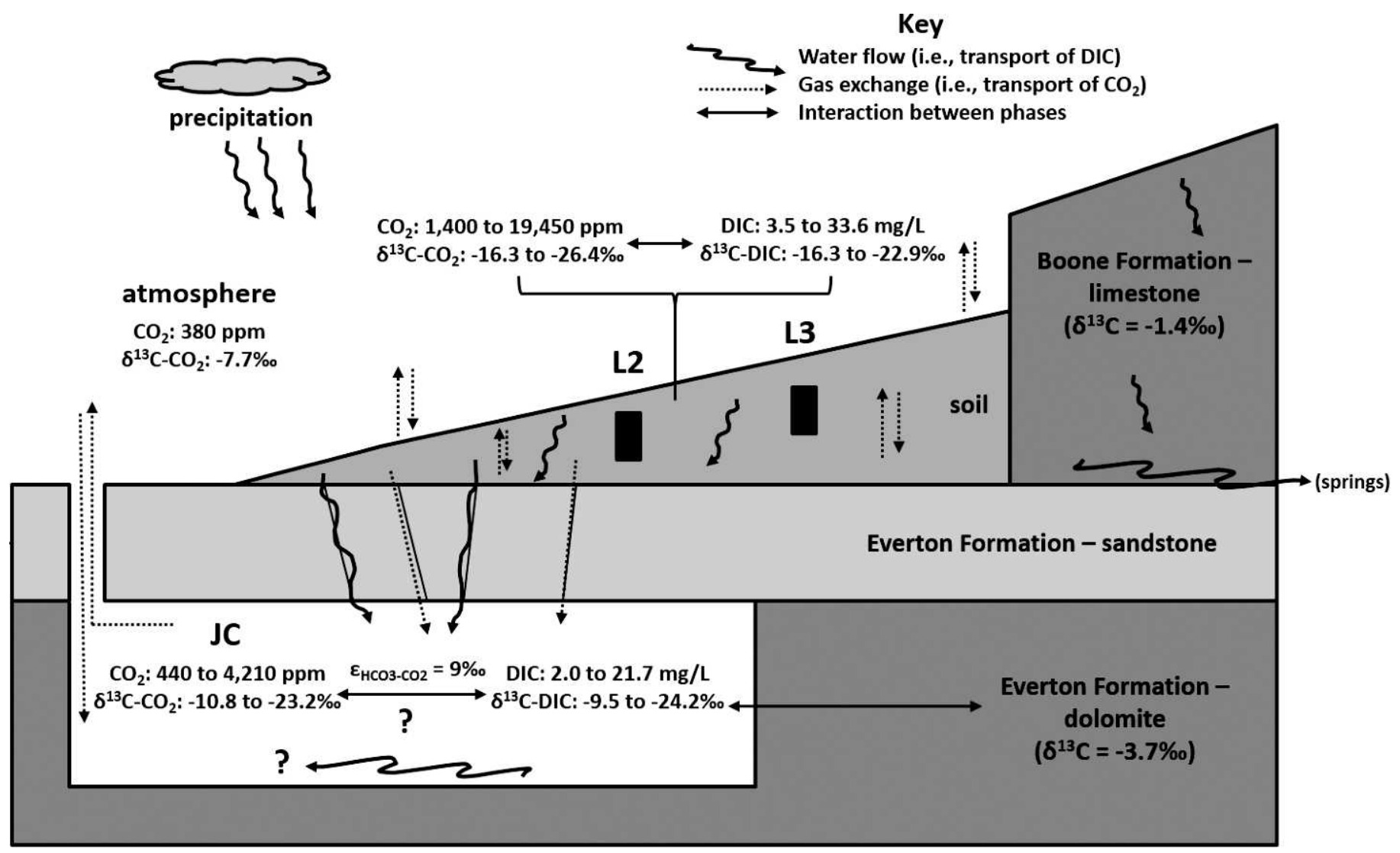

Figure 11. Conceptual model of carbon inputs to Jack's Cave and potential transformations. Groundwater flows from the soil zone, through fractures in the sandstone unit of the Everton Formation, and into the cave, transporting aqueous DIC into the cave. Gaseous $\mathrm{CO}_{2}$ in the cave is a mix between atmospheric $\mathrm{CO}_{2}$ and lighter end-member sources, likely from the soil zone.

1998), which would result in lower soil $\mathrm{CO}_{2}$ concentrations during winter and early spring in northwestern Arkansas (Fig. 4a). Minimum daily surface temperature explained $83 \%$ of the variation in cave $\mathrm{CO}_{2}$ at the Jack's Cave sampling site (Fig. 5a), indicating that surface temperature variation is an important ventilation control in Jack's Cave. Air pressure was not measured during this study, but air pressure has been found to be an important control on cave ventilation in other systems (Palmer, 2007). From November to April, the surface atmosphere is relatively cooler and denser than the cave atmosphere, causing movement of air with lower $\mathrm{CO}_{2}$ concentration and heavier $\delta^{13} \mathrm{C}^{-\mathrm{CO}_{2}}$ into the cave. Cave ventilation is complex, and there are examples where temperature-controlled density gradients do not cause ventilation (Baldini et al., 2008), but the seasonal change in $\mathrm{CO}_{2}$ concentration at site $\mathrm{JC}$ follows closely with changes in surface temperature (Fig. 5a). Additionally, substantial amounts of surface atmosphere can be driven through fractures and pores and into caves (Palmer, 2007), especially caves overlain by fractured sandstone caprock such as Jack's Cave.

As surface temperature warms from May to October, the relatively cooler cave atmosphere is denser than the surface atmosphere, allowing little exchange, and resulting in $\mathrm{CO}_{2}$ build-up in the cave (Fig. 4a). Soil gas is proposed to contribute a substantial component of the cave atmosphere during this time, resulting in higher $\mathrm{CO}_{2}$ concentration and lighter $\delta^{13} \mathrm{C}-\mathrm{CO}_{2}$ (Fig. 11). The isotopic composition of cave atmosphere $\mathrm{CO}_{2}$ was mostly constrained by mixing between atmospheric $\mathrm{CO}_{2}$ (approximately $380 \mathrm{ppm}$ and $-7.7 \%$ ) and two lighter end-member sources with isotopic compositions of $-14 \%$ and $-30 \%$ (Fig. 6). Note that soil $\mathrm{CO}_{2}$ represents a mixture of atmospheric $\mathrm{CO}_{2}$ and soil-respired $\mathrm{CO}_{2}$ (Davidson, 1995), and $\mathrm{CO}_{2}$ respired from $\mathrm{C} 3$ plants, which dominate plants species, can range from $-24 \%$ to $-30 \%$ (Clark and Fritz, 1997; Šantrůčková et al., 2000). Therefore, the end-member compositions for the two mixing lines $(-14 \%$ and $-30 \%$ ) may represent two different soil $\mathrm{CO}_{2}$ isotopic compositions, depending on the degree of mixing between respired $\mathrm{CO}_{2}$ and atmospheric $\mathrm{CO}_{2}$ in the soil zone (Fig. 11). Although the concentration and isotopic composition of $\mathrm{CO}_{2}$ in the soil did vary month-to-month (Fig. 4), the endmember compositions of $-14 \%$ and $-30 \%$ do not clearly represent two distinct seasonal pools of soil $\mathrm{CO}_{2}$, such as a winter versus a summer soil $\mathrm{CO}_{2}$ source to Jack's Cave. The variability of $\mathrm{CO}_{2}$ in the soil zone, prior to entering the cave, may need to be investigated on shorter timescales 
than monthly to further constrain these two lighter endmember sources for $\mathrm{CO}_{2}$.

Although a seasonal pattern in $\mathrm{CO}_{2}$ concentration was observed in the cave, $\delta^{13} \mathrm{C}-\mathrm{CO}_{2}$ did not follow this same pattern throughout the winter (Fig. 4b). An excursion towards lighter $\delta^{13} \mathrm{C}-\mathrm{CO}_{2}$ was observed between January and February, and this pattern was also observed in cave $\delta^{13} \mathrm{C}$-DIC (Fig. 7b). The January and February $\mathrm{CO}_{2}$ isotopic compositions lie just outside of the mixing line between atmospheric $\mathrm{CO}_{2}$ and the possible soil $\mathrm{CO}_{2}$ source with $\delta^{13} \mathrm{C}-\mathrm{CO}_{2}$ of $-30 \%$ (Fig. 6), indicating omission of an apparently minor source of carbon in the mixing model. However, the source of the lighter end member $\mathrm{CO}_{2}$ in the cave during the winter, when soil respiration rates were lowest, is not fully understood. Therefore, in Jack's Cave, the pattern of $\mathrm{CO}_{2}$ concentration is proposed to be driven by changes in surface temperature, but the isotopic composition of winter $\mathrm{CO}_{2}$ requires further investigation.

Similarly to the relationship observed in soil, the increase in DIC concentration at sample site JC with higher surface temperature (Fig. 8a) represents an increased contribution of $\mathrm{CO}_{2}$ derived from soil respiration being transferred to the cave environment via the aqueous phase (Fig. 11). As groundwater interacts with carbonate bedrock, the organic signature from the soil is diluted, because inorganic carbon is added by carbonate dissolution, as evidenced by the heavier $\delta^{13} \mathrm{C}$-DIC in the cave water than soil water (Fig. 9). Calcium carbonate dissolution is also temperature dependent, as greater dissolution can be driven by higher soil $\mathrm{CO}_{2}$ inputs in open systems, but a greater degree of dissolution contributes more carbon from $\mathrm{CaCO}_{3}$, which is isotopically heavier. For example, dissolution of the carbonate bedrock from the Boone and Everton Formations, which averaged $-1.4 \%$ and $-3.7 \%$, respectively, could provide relatively heavier $\delta^{13} \mathrm{C}$-DIC to cave waters, so the correlation between DIC concentration and surface temperature is not as strong in the cave as in the soil (Fig. 8a).

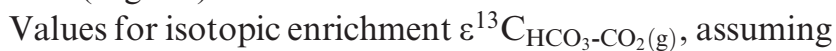
isotopic equilibrium conditions in the cave environment, were $9.1 \%$ \pm 0.1 , based on the range of temperature and $\mathrm{pH}$ values at site JC (Table 2). The observed $\Delta^{13} \mathrm{C}_{\mathrm{DIC}_{-C O}}(\mathrm{~g})$ values in the cave were between $-12.7 \%$ and $+5.1 \%$ o (Fig. 10), indicating that DIC and $\mathrm{CO}_{2}$ were not in isotopic equilibrium. Isotopic disequilibrium between carbon species was also observed in an Austrian cave and attributed to kinetically induced fractionation due to $\mathrm{CO}_{2}$ degassing from infiltrating drip water that was supersaturated with aqueous $\mathrm{CO}_{2}$ compared to the low $\mathrm{CO}_{2}$ cave atmosphere during the winter (Spötl et al., 2005). The degree of DIC-CO $\mathrm{C}_{2}$ isotopic disequilibrium changed seasonally in Jack's Cave (Fig. 10). From December to February and again in May to June, $\Delta{ }^{13} \mathrm{C}_{\text {DIC-CO }}$ (g) values were positive, with DIC isotopically heavier than $\mathrm{CO}_{2}$, and closer to the equilibrium value of 9.1\%o (Clark and Fritz, 1997). This is opposite to what
Spötl et al. (2005) described, where isotopic disequilibrium was greatest during the winter because of kinetic fractionation via $\mathrm{CO}_{2}$ degassing. In Jack's Cave, the extent of possible degassing is not known. However, the $\Delta \Delta^{13} \mathrm{C}_{\mathrm{DIC}-\mathrm{CO}_{2}(\mathrm{~g})}$ values transitioned between positive and negative during November/December and March/April when the $\mathrm{CO}_{2}$ in the cave was changing (Fig. 10), indicating that ventilation was likely driving changes in isotopic disequilibrium. Therefore, the rapid addition or removal of $\mathrm{CO}_{2}$ via cave atmospheric exchange between the cave and the surface appears to lead to isotopic disequilibrium between gaseous $\mathrm{CO}_{2}$ and aqueous DIC. During periods of more stable air, when $\mathrm{CO}_{2}$ concentration was not rapidly increasing or decreasing, the aqueous DIC in the cave water and gaseous $\mathrm{CO}_{2}$ in the cave atmosphere were closer to isotopic equilibrium (Fig. 10).

In cave water, $\mathrm{Ca}$ and $\mathrm{Mg}$ concentrations can be controlled by the degree of rock-water interaction, $\mathrm{CO}_{2}$ concentration in the soil and cave, and dilution via meteoric water (Spötl et al., 2005; Tooth and Fairchild, 2003; Wong et al., 2011). Between December and March precipitation was low (Fig. 3) and water flow into Jack's Cave decreased, so an increase in $\mathrm{Ca}$ and $\mathrm{Mg}$ concentrations would be expected due to greater rock-water interaction. However, $\mathrm{Ca}$ and $\mathrm{Mg}$ concentrations remained low in the cave during the winter and spring, following the same pattern as DIC. Prior calcite precipitation could account for the observed pattern in $\mathrm{Ca}$, but the lack of secondary calcite in the cave pool, rapid infiltration of meteoric water due to direct hydrologic connections between the soil zone and the shallow cave (Knierim et al., 2011), and lower $\mathrm{Mg} / \mathrm{Ca}$ ratios during the winter make prior calcite precipitation an unlikely mechanism. The seasonal change in cave $\mathrm{CO}_{2}$ is interpreted as retarding carbonate-rock dissolution during winter periods of low $\mathrm{CO}_{2}$ concentration, but did not result in calcite supersaturation and enhanced precipitation of calcite. If calcite precipitation versus dissolution is considered on a continuum of $\mathrm{CaCO}_{3}$ solubility, as controlled by $\mathrm{CO}_{2}$ input, then these results are consistent with other studies that found cave $\mathrm{CO}_{2}$ correlated with $\mathrm{Mg}$ and $\mathrm{Ca}$ concentrations in cave water (Spötl et al., 2005; Wong et al., 2011), but they illustrate that Jack's Cave is dominated by varying degrees of dissolution.

\section{Conclusions}

Heterogeneity in soil properties within small areas can greatly affect interpretations of carbon transfer and is especially important in shallow karst systems. For example, $\mathrm{CO}_{2}$ in L3 - drier soil site-increased exponentially with increasing surface temperature, whereas at L2 -wetter soil site-soil $\mathrm{CO}_{2}$ decreased exponentially and $\delta^{13} \mathrm{C}-\mathrm{CO}_{2}$ became relatively lighter with increasing precipitation. Qualitative differences in soil moisture between the two sites contributed to how soil $\mathrm{CO}_{2}$ from soil respiration was 
affected by changes in surface temperature and precipitation.

Both soil sites showed a seasonal correlation between aqueous DIC concentration and isotopic composition, indicating an organic carbon source for a component of DIC and corroborating soil DIC as a proxy for soil respiration. In the cave, the positive correlation between DIC and surface temperature was also due to increased soil respiration as organic carbon was oxidized in the soil zone and transferred to the cave environment via the aqueous phase. However, aqueous $\delta^{13} \mathrm{C}$-DIC was heavier in the cave than in the soil, because the organic signature from soil respiration was diluted by a portion of the inorganic carbon being derived from carbonate dissolution.

Cave atmosphere $\mathrm{CO}_{2}$ at site JC increased exponentially with increasing surface temperature, possibly due to changing ventilation patterns between the surface and cave atmospheres. The winter period of low $\mathrm{CO}_{2}$ concentration in the cave is interpreted to mean that carbonate dissolution was reduced, thus lowering the concentration of $\mathrm{Ca}$ and $\mathrm{Mg}$ in cave water. Therefore, in some environments, such as a shallow karst system capped by sandstone, cave-atmosphere composition can provide information about controls on the geochemistry of small cave streams fed by drip water.

Isotopic disequilibrium between $\mathrm{CO}_{2}$ and DIC in the cave was greatest when ventilation patterns were presumably changing in the spring and fall, with the associated rapid addition or removal of gaseous $\mathrm{CO}_{2}$. The isotopic disequilibrium between DIC and $\mathrm{CO}_{2}$ provided evidence that cave $\mathrm{CO}_{2}$ was a mixture of carbon from several sources, which was mostly constrained to mixtures between atmospheric $\mathrm{CO}_{2}$ and soil $\mathrm{CO}_{2}$. The isotopic composition of cave $\mathrm{CO}_{2}$ did not follow the same pattern as $\mathrm{CO}_{2}$ concentration, and an excursion towards lighter $\delta^{13} \mathrm{C}-\mathrm{CO}_{2}$ during the winter is not fully understood. The winter $\mathrm{CO}_{2}$ compositions lay just outside of the mixing line between atmospheric $\mathrm{CO}_{2}$ and soil $\mathrm{CO}_{2}$, indicating omission of an apparently minor source of carbon in the mixing model.

In a conceptual model of carbon inputs and transformations at the study site, aqueous DIC and gaseous $\mathrm{CO}_{2}$ are transported into the cave from the soil zone, with variable amounts of the cave atmosphere $\mathrm{CO}_{2}$ also being sourced directly from the surface atmosphere. The magnitude of different source inputs to the cave changed seasonally, as evidenced by the month-to-month variability of $\mathrm{CO}_{2}$ and DIC concentrations and isotopic compositions during the study period. Characterizing the carbon species over time in the unsaturated zone of a mantled karst setting, although challenging, was important for understanding the variability of carbon species observed in the underlying cave. Additionally, isotopic disequilibrium between carbon species provided insight into the sources of carbon in the cave environment. Stable carbon isotope ratios provided an effective tool to explore carbon transfer from the soil zone into the cave, identify carbon sources in the cave, and investigate how seasonality affected the transfer of carbon in a shallow karst system. Jack's Cave in northwestern Arkansas provides a representative example of mechanisms for inorganic carbon transfer in a shallow karst system covered by a regolith mantle.

\section{ACKNOWLEDGEMENTS}

Funding was provided by the Arkansas Water Resources Center through the U.S. Geological Survey 104b Program. Any use of trade, firm, or product names is for descriptive purposes only and does not imply endorsement by the U.S. Government. Comments from two anonymous reviewers and the associate editor greatly improved this manuscript. Special thanks to the Carroll family for use of their property.

\section{REFERENCES}

Adamski, J.C., Petersen, J.C., Freiwald, D.A., and Davis, J.V., 1995, Environmental and Hydrologic Setting of the Ozark Plateaus Study Unit, Arkansas, Kansas, Missouri, and Oklahoma: U.S. Geological Survey, Water-Resources Investigations Report, 94-4022, 69 p.

Baldini, J.U.L., Baldini, L.M., McDermott, F., and Clipson, N., 2006, Carbon dioxide sources, sinks, and spatial variability in shallow temperate zone caves: Evidence from Ballynamintra Cave, Ireland: Journal of Cave and Karst Studies, v. 68, p. 4-11.

Baldini, J.U.L., McDermott, F., Hoffman, D.L., Richards, D.A., and Clipson, N., 2008, Very high-frequency and seasonal cave atmosphere $\mathrm{P}_{\mathrm{CO} 2}$ variability: Implications for stalagmite growth and oxygen isotope-based paleoclimate records: Earth and Planetary Science Letters, v. 272, p. 118-129. doi:10.1016/j.epsl.2008.04.031.

Borken, W., Davidson, E.A., Savage, K., Gaudinski, J., and Trumbore, S.E., 2003, Drying and wetting effects on carbon dioxide release from organic horizons: Soil Science Society of America Journal, v. 67, p. 1888-1896. doi:10.2136/sssaj2003.1888.

Boyer, D.G., and Pasquarell, G.C., 1999, Agricultural land use impacts on bacterial water quality in a karst groundwater aquifer: Journal of the American Water Resources Association, v. 35, p. 291-300. doi:10.1111/j.1752-1688.1999.tb03590.x.

Breecker, D.O., Payne, A.E., Quade, J., Banner, J.L., Ball, C.E., Meyer, K.W., and Cowan, B.D., 2012, The sources and sinks of $\mathrm{CO}_{2}$ in caves under mixed woodland and grassland vegetation: Geochimica et Cosmochimica Acta, v. 96, p. 230-246. doi:10.1016/j.gca.2012.08.023.

Brye, K.R., West, C.P., and Gbur, E.E., 2004, Soil quality differences under native tallgrass prairie across a climosequence in Arkansas: The American Midland Naturalist, v. 152, p. 214-230.

Clark, I.D., and Fritz, P., 1997, Environmental Isotopes in Hydrogeology: Boca Raton, New York, Lewis Publishers, 352 p.

Coplen, T.B., 1996, New guidelines for reporting stable hydrogen, carbon, and oxygen isotope-ratio data: Geochimica et Cosmochimica Acta, v. 60, p. 3359-3360. doi:10.1016/0016-7037(96)00263-3.

Davidson, E.A., Belk, E., and Boone, R.D., 1998, Soil water content and temperature as independent or confounded factors controlling soil respiration in a temperate mixed hardwood forest: Global Change Biology, v. 4, p. 217-227. doi:10.1046/j.1365-2486.1998.00128.x.

Davidson, G.R., 1995, The stable isotopic composition and measurement of carbon in soil $\mathrm{CO}_{2}$ : Geochimica et Cosmochimica Acta, v. 59, p. 2485-2489. doi:10.1016/0016-7037(95)00143-3.

Davis, R.K., Brahana, J.V., and Johnston, J.S., 2000, Ground Water in Northwest Arkansas: Minimizing Nutrient Contamination from NonPoint Sources in Karst Terrane: Fayetteville, Arkansas Water Resources Center, Publication Number MSC-288, 173 p.

Doctor, D.H., Alexander, E.C. Jr., Petrič, M., Kogovšek, J., Urbanc, J., Lojen, S., and Stichler, W., 2006, Quantification of karst aquifer discharge components during storm events through end-member mixing analysis using natural chemistry and stable isotopes as tracers: 
Hydrogeology Journal, v. 14, p. 1171-1191. doi:10.1007/s10040-0060031-6.

Fairchild, I.J., Smith, C.L., Baker, A., Fuller, L., Spötl, C., Mattey, D., McDermott, F., and E.I.M.F., 2006, Modification and preservation of environmental signals in speleothems: Earth-Science Reviews, v. 75, p. 105-153. doi:10.1016/j.earscirev.2005.08.003.

Faure, G., 1986, Principles of Isotope Geology, second edition: New York, John Wiley \& Sons, Inc., 608 p.

Faure, G., and Mensing, T.M., 2005, Isotopes: Principles and Applications: Hoboken, N.J., John Wiley and Sons, Inc., 928 p.

Fetter, C.W. Jr., 2001, Applied Hydrogeology, fourth edition: Upper Saddle River, New Jersey, Prentice Hall, 598 p.

Fisher, J.B., Whittaker, R.J., and Malhi, Y., 2011, ET come home: Potential evapotranspiration in geographical ecology: Global Ecology and Biogeography, v. 20, p. 1-18. doi:10.1111/j.1466-8238.2010.00578.x.

Graening, G.O., and Brown, A.V., 2000, Trophic Dynamics and Pollution Effects in Cave Springs Cave, Arkansas: Fayetteville, Arkansas Water Resources Center, Publication Number MSC-285, $46 \mathrm{p}$

Johnson, T.C., 2008, Geologic map of Forum Quadrangle with a karst inventory, Madison County, Arkansas [M.S. Thesis]: Fayetteville, The University of Arkansas, $188 \mathrm{p}$.

Katz, B.G., Coplen, T.B., Bullen, T.D., and Davis, J.H., 1997, Use of chemical and isotopic tracers to characterize the interactions between ground water and surface water in mantled karst: Ground Water, v. 35, p. 1014-1028. doi:10.1111/j.1745-6584.1997.tb00174.x.

Kendall, C., 1998, Tracing nitrogen sources and cycling in catchments, in Kendall, C., and McDonnell, J.J., eds., Isotope Tracers in Catchment Hydrology: Amsterdam, Elsevier Science, p. 519-576.

Knierim, K.J., 2009, Seasonal variation of carbon and nutrient transfer in a northwestern Arkansas cave [M.S. Thesis]: Fayetteville, University of Arkansas, $141 \mathrm{p}$

Knierim, K.J., Pollock, E.D., and Hays, P.D., 2011, Using labeled isotopes to trace groundwater flow paths in a northwestern Arkansas cave, in Kuniansky, E.L., ed., U.S Geological Survey Karst Interest Group Proceedings, Fayetteville, Arkansas, April 26-29, 2011: U. S. Geological Survey, Scientific Investigations Report 2011-5031, p. $67-73$

Kowalczk, A.J., and Froelich, P.N., 2010, Cave air ventilation and $\mathrm{CO}_{2}$ outgassing by radon-222 modeling: How fast do caves breathe?: Earth and Planetary Science Letters, v. 289, p. 209-219. doi:10.1016/ j.epsl.2009.11.010.

Lee, Eung Seok, and Krothe, N.C., 2001, A four-component mixing model for water in a karst terrain in south-central Indiana, USA: Using solute concentration and stable isotopes as tracers: Chemical Geology, v. 179, p. 129-143. doi:10.1016/S0009-2541(01)00319-9.

Lohse, K.A., Brooks, P.D., McIntosh, J.C., Meixner, T., and Huxman, T.E., 2009, Interactions between biogeochemistry and hydrologic systems: Annual Review of Environment and Resources, v. 34, p. 65-96. doi:10.1146/annurev.environ.33.031207.111141.

National Cooperative Soil Survey, 2008, Custom Soil Report for Madison County, Arkansas: United States Department of Agriculture, Natural Resources Conservation Service, 16 p.

National Oceanic and Atmospheric Administration, 2009, Arkansas Northwest Division 01, 1895-2009, http://www7.ncdc.noaa.gov/ CDO/CDODivisionalSelect.jsp [date accessed March 3, 2010].

Palmer, A.N., 2007, Cave Geology: Dayton, Ohio, Cave Books, 454 p.

Peyraube, N., Lastennet, R., Denis, A., and Malaurent, P., 2013, Estimation of epikarst air $\mathrm{P}_{\mathrm{CO} 2}$ using measurements of water $\delta^{13} \mathrm{C}_{\mathrm{TDIC}}$, cave air $\mathrm{P}_{\mathrm{CO} 2}$ and $\delta^{13} \mathrm{C}_{\mathrm{CO} 2}$ : Geochimica et Cosmochimica Acta, v. 118, p. 1-17. doi:10.1016/j.gca.2013.03.046.
Phillips, D.L., and Koch, P.L., 2002, Incorporating concentration dependence in stable isotope mixing models: Oecologia, v. 130, p. 114-125. doi:10.1007/s004420100786.

Pronk, M., Goldscheider, N., and Zopfi, J., 2006, Dynamics and interaction of organic carbon, turbidity and bacteria in a karst aquifer system: Hydrogeology Journal, v. 14, p. 473-484. doi:10.1007/ s10040-005-0454-5.

Révész, K.M., and Landwehr, J.M., 2002, $\delta^{13} \mathrm{C}$ and $\delta^{18} \mathrm{O}$ isotopic composition of $\mathrm{CaCO}_{3}$ measured by continuous flow isotope ratio mass spectrometry: Statistical evaluation and verification by application to Devils Hole core DH-11 calcite: Rapid Communications in Mass Spectrometry, v. 16, p. 2102-2114. doi:10.1002/rcm.833.

Šantrǔčková, H., Bird, M.I., and Lloyd, J., 2000, Microbial processes and carbon-isotope fractionation in tropical and temperate grassland soils: Functional Ecology, v. 14, p. 108-114. doi:10.1046/j.1365-2435.2000. 00402.x.

Sponseller, R.A., 2007, Precipitation pulses and soil $\mathrm{CO}_{2}$ flux in a Sonoran Desert ecosystem: Global Change Biology, v. 13, p. 426-436. doi:10.1111/j.1365-2486.2006.01307.x.

Spötl, C., Fairchild, I.J., and Tooth, A.F., 2005, Cave air control on dripwater geochemistry, Obir Caves (Austria): Implications for speleothem deposition in dynamically ventilated caves: Geochimica et Cosmochimica Acta, v. 69, p. 2451-2468. doi:10.1016/j.gca.2004. 12.009 .

St-Jean, G., 2003, Automated quantitative and isotopic $\left({ }^{13} \mathrm{C}\right)$ analysis of dissolved inorganic carbon and dissolved organic carbon in continuous-flow using a total organic carbon analyser: Rapid Communications in Mass Spectrometry, v. 17, p. 419-428. doi:10.1002/rcm.926.

Taylor, D.S., Goodwin, D.P., Bitting, C.J., Handford, R., and Slay, M., 2009, The Ozark Plateaus: Arkansas, in Palmer, A.N., and Palmer, M.V., eds., Caves and Karst of the USA: Huntsville, Alabama, National Speleological Society, Inc., p. 172-174.

Tooth, A.F., and Fairchild, I.J., 2003, Soil and karst aquifer hydrologic controls on the geochemical evolution of speleothem-forming drip waters, Crag Cave, southwest Ireland: Journal of Hydrology, v. 273, p. 51-68. doi:10.1016/S0022-1694(02)00349-9.

Trautz, R.C., Pugh, J.D., Varadharajan, C., Zheng, Liang, Bianchi, M., Nico, P.S., Spycher, N.F., Newell, D.L., Esposito, R.A., Wu, Yuxin, Dafflon, B., Hubbard, S.S., and Birkholzer, J.T., 2013, Effect of dissolved $\mathrm{CO}_{2}$ on a shallow groundwater system: A controlled release field experiment: Environmental Science and Technology, v. 47, p. 298-305. doi:10.1021/es301280t.

United States Department of Agriculture, 2002, State Fact Sheets: Arkansas, http://www.ers.usda.gov/data-products/state-fact-sheets/statedata.aspx?StateFIPS $=05 \&$ StateName $=$ Arkansas $\#$. VEgT9xY00jZ, [date accessed July 1, 2009].

United States Department of Agriculture, 2007, Quick Stats, http://www. nass.usda.gov/ [date accessed July 1, 2009].

Winston, B., 2006, The biogeochemical cycling of nitrogen in a mantled karst watershed [M.S. Thesis]: Fayetteville, University of Arkansas, $98 \mathrm{p}$.

Wong, C., and Banner, J.L., 2010, Response of cave air $\mathrm{CO}_{2}$ and drip water to brush clearing in central Texas: implications for recharge and soil $\mathrm{CO}_{2}$ dynamics: Journal of Geophysical Research: Biogeosciences, v. 115, article G04018, 13 p. doi:10.1029/2010JG001301.

Wong, C.I., Banner, J.L., and Musgrove, M., 2011, Seasonal dripwater $\mathrm{Mg} / \mathrm{Ca}$ and $\mathrm{Sr} / \mathrm{Ca}$ variations driven by cave ventilation: Implications for and modeling of speleothem paleoclimate records: Geochimica et Cosmochimica Acta, v. 75, p. 3514-3529. doi:10.1016/j.gca.2011. 03.025 . 